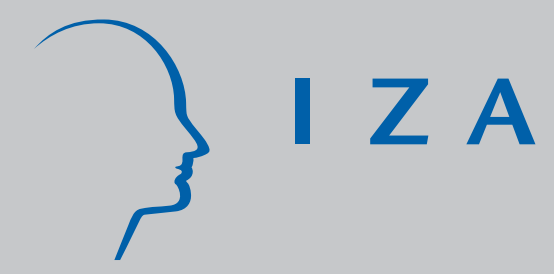

IZA DP No. 2894

Spousal Influences on Parents' Non-Market Time Choices

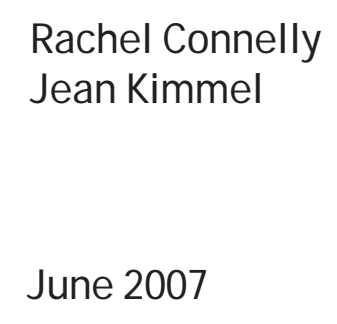

J une 2007 


\title{
Spousal Influences on Parents' Non-Market Time Choices
}

\author{
Rachel Connelly \\ Bowdoin College \\ Jean Kimmel \\ Western Michigan University \\ and IZA
}

Discussion Paper No. 2894

June 2007

IZA

P.O. Box 7240

53072 Bonn

Germany

Phone: +49-228-3894-0

Fax: +49-228-3894-180

E-mail: iza@iza.org

Any opinions expressed here are those of the author(s) and not those of the institute. Research disseminated by IZA may include views on policy, but the institute itself takes no institutional policy positions.

The Institute for the Study of Labor (IZA) in Bonn is a local and virtual international research center and a place of communication between science, politics and business. IZA is an independent nonprofit company supported by Deutsche Post World Net. The center is associated with the University of Bonn and offers a stimulating research environment through its research networks, research support, and visitors and doctoral programs. IZA engages in (i) original and internationally competitive research in all fields of labor economics, (ii) development of policy concepts, and (iii) dissemination of research results and concepts to the interested public.

IZA Discussion Papers often represent preliminary work and are circulated to encourage discussion. Citation of such a paper should account for its provisional character. A revised version may be available directly from the author. 


\section{ABSTRACT \\ Spousal Influences on Parents' Non-Market Time Choices ${ }^{*}$}

This paper considers the effect of spouse's characteristics on three aggregated non-paid time uses, active leisure time; child caregiving time; and home production time, using the American Time Use Survey (ATUS). The time diary of each married individual with children under the age of 13 (mothers and fathers) is analyzed, both in terms of the level of non-paid time and the wife's share of the total level of the daily activity for the couple. Three spousal variables: the relative wage of the wife compared to her husband, spouses' weekly hours of employment; and, in the level equations only, the spouses' time in the same activity are considered. Each of these spousal variables needs to be estimated in order to address issues of both endogeneity and missing data. Three alternative strategies to address these problems are explored: predictions within the sample, predictions from outside the sample and propensity matching which "marries" mothers with time diaries to fathers with time diaries who have propensity scores similar to the women's husband. The results show very little effect of one spouse on the level of other spouse's unpaid time use. This absence of spousal effects is similar to the reduction of spousal effects in employment time described in Blau and Kahn (2005). In terms of the share of wife's time in the activity, we find higher relative wages of the mother compared to her husband leads to a greater share of child care done by the mother on both weekdays and weekends. No consistent effect of relative wages is found on the mother's share of leisure or home production.

JEL Classification: J13, J22

Keywords: time use, non-market time choices, family decision-making

Corresponding author:

Jean Kimmel

Department of Economics

Western Michigan University

Kalamazoo, MI 49008-5091

USA

E-mail: jean.kimmel@wmich.edu

\footnotetext{
* Prepared for presentation at the May/June 2007 IZA Topic Week on Nonmarket Time in Economics held in Bonn, Germany. Earlier drafts presented at the January 2007 ASSA meeting held in Chicago IL and March 2007 PAA meetings held in New York.
} 


\section{Spousal Influences on Parents' Non-Market Time Choices}

Although approximately 50 percent of households in the United States contain married couples, little is known about how these couples make their joint time use decisions. ${ }^{1}$ Recent work by Blau and Kahn (2005) shows that wives’ labor supply decisions are affected less by spousal factors than they once were, but no such trend evidence exists concerning unpaid uses of time. We examine three types of out-ofmarket time: leisure, unpaid household production and caregiving time, with a focus on the role of spousal factors in time choices.

Why might we expect spousal factors to affect time use choices? Economic models of marriage emphasize the "gains from marriage"; namely, that there are sufficient benefits to forming a marriage partnership that both partners can experience an improvement in well-being upon marriage. This gain can come from gains from specialization or gains from complementarities. Gains from specialization relies on the existence of fairly fixed quantities of requisite household goods that can be produced by either the husband or the wife. For example, if dinner needs cooking, one member of the couple may do the cooking while the other tends to the children or (could it be?) reads the newspaper. Thus, we might expect that increased home production time of one spouse would reduce the home production time of the other spouse.

If the gains from marriage come from complementarities, such as enjoying spending leisure time with one's spouse, then we might predict that an increase in the leisure time of one spouse would also increase the leisure time of the other spouse. Hamermesh (2000), Hallberg (2003) and Jenkins and Osberg (2005) find evidence of this

\footnotetext{
${ }^{1}$ This 50 percent figure reflects a steady decline in recent decades. See, for example, recent NY Times article from Nov. 2006.
} 
desire for simultaneous leisure. Similar tastes increase the gains from marriage (Lam, 1988) and may lead to positive correlation in time uses other than leisure. For example, a man who likes a neat house marries a woman who likes a neat house and they both spend more time on home production.

In this paper we use the American Time Use Surveys from 2003 and 2004 to consider the effect of spouse's characteristics on three aggregated non-paid time uses: active leisure time, child caregiving time and home production time. Kimmel and Connelly (2007) showed that child caregiving time must be treated distinctly from either leisure or home production. Because of our interest in caregiving, in particular, and in couples rather than individual decision making, only married individuals with children under the age of 13 are included in the sample. We analyze maternal and paternal time use measured as the level of non-paid time, that is, the number of minutes in the activity on the day to which the survey refers, and measured as the wife's share of the total level of the daily activity for the couple. Level and share are clearly related but the share approach abstracts for difference across families in the chosen amount of caregiving and home production, focusing directly on the relative contribution husbands and wives make to the household production function.

The three spousal variables of interest are the relative wage of the wife compared to her husband, which represents the relative value of her time versus his in non-paid activities and may also be a proxy for relative bargaining power within the household; spouse's weekly hours of employment, which controls for the underlying time constraint in time use decision making; and, in the level equations only, the spouse's time in the same activity, which would be negatively related to own time use if a fixed level of 
product is desired but would be positively related to own time use if the level is a function of positively correlated tastes. Each of these spousal variables needs to be instrumented in order to address issues of both endogeneity and missing data. We use three alternative strategies to address these problems: predictions within sample, predictions from outside the sample and a propensity matching strategy which "marries" mothers with time diaries to fathers with time diaries who have propensity scores similar to each women's actual husband.

As the literature review below makes clear, we are certainly not the first to ask the general question of what role wives play in husbands' time use decision making or vice versa. But many of the other papers look at a single time use. For example, a large body of work has focused on unpaid housework alone, while others have looked solely at leisure time. Our model estimates the three time use equations simultaneously to allow for a correlated error structure. An earlier body of work such as Kooreman and Kapteyn (1987) and Solberg and Wong (1992) did consider multiple non-paid time uses but those authors were constrained by the lack of recent time diary data. Finally, we control for usual employment hours of the husband and wife such that wage differences represent differences in the opportunity cost of the couples' time. Many of the previous studies used relative income, thereby confounding wage effects and hours of work effects.

Through a variety of estimation strategies, we find very little evidence that one's spouse's characteristics affect a mother's or father's daily non-paid time use. Home production levels are particularly immune from spousal effects except perhaps that increased husband's home production on the weekends actually increases the wife's home production. Might guilt play a role here or is it just higher household cleanliness 
standards? ${ }^{2}$ There may be more substantial effects of spouse characteristics on the share of the total couple's time performed by the wife but in these estimations, we are plagued by the lack of data on actual couples' time use and so the results are more tenuous. Two robust relationships emerge in the share models, both of which relate to child caregiving. Using the father's sample, increased weekly employment hours of his wife reduces her share of caregiving time while using the mother's sample, increased wages of the wife relative to her husband increases her share of caregiving.

The rest of the paper proceeds as follows: Section II presents a brief literature review. A discussion of the theoretical underpinnings of the empirical models is offered in Section III. Section IV describes our ATUS data and provides descriptive statistics. The econometric strategy is discussed in Section V, while the results of the estimation are presented in Sections VI and VII. Section VI provides the results for the levels of nonpaid time, that is, the minutes of time in a 24 hour period devoted to active leisure, child caregiving and household production. The share of the wife's time models are reported in Section VII. Section VIII provides concluding remarks.

\section{Section II: Previous Research on Married Couples Joint Time Use Decision Making}

Research from four separate but intersecting literatures are relevant to the analysis of spousal effects on non-paid time use decision making. These four literatures are: the literature of joint labor supply, household bargaining models, housework differentials within a couple and the analysis of time diary data. Each is reviewed only briefly.

\footnotetext{
2 What we have called guilt here may also be what Bittman et al (2003) refer to as “doing gender”. The idea is that women need to appear to others as the one who performs the housework.
} 
There is a long literature on married couples joint labor supply. See Killingsworth (1983) for an early review. Hausman and Ruud (1984), Lundberg (1988) and Ransom (1987) explicitly modeled joint as opposed to individual labor supply. Blundell and MaCurdy (1999) provide a more recent summary of the empirical results focusing on couple’s labor supply. Even more recently, Devereux (2004) estimated the effect of changes in relative wages on husbands and wives' labor supply. He found that men are largely unaffected by their wives’ labor supply but the wife's own wage effect is positive and their response to increasing wages for their husbands is negative. Blau and Kahn (2005) find that the own wage and cross wage effects on married women's labor supply have declined in magnitude from 1980 to 2000, such that married women’s labor supply behaves much like married men's in 2000, with small own wage and cross wage elasticities.

The household bargaining model literature provides one theoretical framework for understanding why we might expect husband and wife’s time use to be related. Moving beyond the unitary model of household decision making proposed by Becker (1991), bargaining model proponents argue that the source of income is an important determinant of who ultimately consumes the items purchased by the family. The same would be expected to be true for leisure consumption. The relative wage is expected to determine power within the household, either due to its relationship to income outside the marriage as in the divorce threat point models of McElroy and Horney (1981) and Manser and Brown (1980), the collective framework models of Chiappori and colleagues (Chiappori, 1988; Browning and Chiappori, 1998; and Chiappori, Fortin and Lacroix, 2002), or in the separate spheres threat point of Lundberg and Pollak (1993). Empirical work based on 
these bargaining models have confirmed the relevance of a bargaining approach in understanding joint labor supply (Fortin and Lacroix, 1997 and Chiappori, Fortin and Lacroix, 2002), expenditures on women and children's health (Thomas, 1990), and expenditures on children's clothing (Lundberg, Pollak and Wales, 1997).

Housework has been a particular research focus in the area of couples' time allocation because changes in women's labor supply have not brought equal changes in the distribution of tasks within the household. While women have substantially reduced their home production time and men have somewhat increased theirs, women continue to do a majority of the housework. For example, Hersch and Stratton (2002) report data from the National Survey of Families and Households (NSFH) from 1987-88 which shows that married women do almost 30 hours of home production a week, compared to 18 hours for married men. Sousa-Poza, Schmid and Widmer (2001) report on 1997 data from Switzerland that men, on average, spend about half as much time on housework as women. Married men spend less time than non-married men on housework while married women spend more time than non-married women. Bittman et al. (2003) report that in 1992, Australian wives averaged 23 hours of housework a week compared to 11 hours for their husbands. And using 1991 data from Spain, Alvarez and Miles (2003) report that "women do almost all the housework in nearly $75 \%$ of the two-earner households.” (p. 228) Hersch and Stratton (1994), using data from the PSID from 1979 to 1987 , showed that the share of housework a husband performed in a dual earner couple was negatively related to his share of labor income and to his share of labor market hours. When the analysis is conducted separately for husband's time and wife's time, the husband's model explains little of the variance in time. This insensitivity of husband's 
housework time to his and his wife's observable characteristics was also found in the Swiss and Spanish data. Alvarez and Miles (2003) offer an Oaxaca decomposition which shows that most of the inequality in housework comes from gender-specific effects rather than differences in observable characteristics. Bittman et al. (2003) reviews the sociological housework literature for both Australia and the U.S. Their model of Australian housework time included both a measure of relative annual income and usual weekly hours of employment for both husbands and wives. They find that for wives, the husband's share of income has a negative impact on her weekly housework time but only up to the point where their share becomes equal. When wives earn more than their husbands, wives are found to spend more time in housework. For husbands, only his time in employment and his wife's time in employment matter.

Finally, we briefly review the literature on the determinants of couples' time use patterns obtained from time diary studies. The bulk of the previous time use research relying on time diaries has examined the joint time use decisions of dual earner households. Kooreman and Kapteyn (1987), using U.S time diary data from 1975-76, found that the husband's own wages and his wife's wages had little effect on seven different types of non-market time. Non-paid time for wives in 1975-76 was found to be more elastic to changes in their own wage and their husband's wage. One might speculate that these results from data thirty years ago may be as different today as the changes noted by Blau and Kahn (2005) in their examination of labor supply elasticities.

Solberg and Wong (1992) use U.S. data from 1977-78 to estimate time use for husbands and wives in three aggregate categories: leisure, household production, and paid work. Like the studies of housework described above, they found that husband's 
household production was unaffected by either his wage or his wife's wage. Only the husband's own travel time to work time seems to affect his housework time. Men's leisure was positively affected by both his own wage and his wife's wage, while her leisure was only affected by her husband's wage and her housework was negatively affected by her own wage.

Looking at currently employed married mothers using more recent data from the Netherlands, Van Den Brink and Groot (1997) found no effect of husband's earnings on the time allocation of his wife in employment, home production or child care. Hallberg and Klevmarken (2003) examine the determinants of parents' time allocated to childcare in Sweden using a structural model that incorporates instruments for both parents' wages and parents' employment time. They find that own wages do not affect child care time. Kalenkoski, Ribar and Stratton (2006) examine the role of wages on parents' time choices. Using time use data from the United Kingdom, they examine parents' time use in three activities: primary caregiving, secondary caregiving, and paid work time. They include as regressors the parent's own wage as well as the spouse's wage. They find that spousal wages are, for the most part, unimportant in parental time choices. Finally, a recent paper by Freidberg and Webb (2006) explicitly marries the bargaining model approach to time use research. They argue that relative wages are a good proxy for bargaining power within the household in determining the spousal household production split. They find significant effects of the relative wage only on television watching and cleaning the house, but even these statistically significant effects are small. Overall, there is little consistent evidence concerning the roles of own wage, spousal wage, or relative wage on time allocation decisions. 
Our paper differs from Freidberg and Webb's in that we include weekdays as well as weekends and we control for weekly hours of employment. More importantly, we introduce statistical strategies to overcome the lack of daily time use information for the spouse of the time diary respondent. Our results, however, are consistent with theirs and many of the others just reviewed. We find little or no effect of one spouse's economic factors on the other spouse's time use patterns.

\section{Section III: Theoretical Underpinnings and Estimation}

Our underlying utility-maximizing framework relies on an extension of the model developed by Kimmel and Connelly (2007) to include spousal time inputs in non-market production of goods and services, including child services. Kimmel and Connelly (2007) developed an extended Gronau-type model of time use in which mothers allocate their time among five choices: paid work, unpaid household production, caregiving, leisure, and other activities. That model focused on the decision making of the mother with no explicit role for her hsuband in time use decisions except in terms of his earnings capacity. For the analysis in this paper, we modify that theoretical framework so that for married couples with young children, non-market goods and services (including child services) are produced with time inputs from both parents. Spousal time inputs are incorporated into the household goods production function and the child services production function.

A complete listing of model equations and notation is found in Appendix A. We describe the full model only briefly here. In this model, the individual spouse maximizes his/her utility over leisure time, adult goods, and child services subject to a series of 
production functions and constraints. Both household goods and child services are produced with a combination of each parent's time and purchased market goods (intermediate market goods in the case of the household production). An individual's time can be allocated to five distinct activities: active leisure, paid market work, unpaid household production, caregiving, and a composite fifth category that includes sleep, human capital investment time, and personal care/grooming. ${ }^{3}$

Maximization of this spousal utility function subject to the five model constraints yields typical consumer demand equations as well as the time demand equations given below:

$$
t_{i j}=f(w, P c c, V \mid Z, H, D) \quad \text { for } i=m, f \text { and } j=e m, h p, m c c, L, s
$$

In the above equation, w denotes various wage measures to be described below, Pcc is the price of child care, and $\mathrm{Z}, \mathrm{H}$, and $\mathrm{D}$ are control variables that are also discussed in the next section. Because of our focus in this paper on unpaid time use, we examine only three uses of time: active leisure time, unpaid household production (excluding caregiving), and caregiving. ${ }^{4}$ This results in six total system equations, three for the husband and three for the wife. Ideally, this six equation model would be estimated jointly. However, data constraints, most importantly the lack of time diary information for the spouse lead us to consider alternative specifications as outlined below.

\footnotetext{
${ }^{3}$ For our measure of active leisure, we exclude time spent sleeping or engaging in personal care. See Kimmel and Connelly (2007) and Aguiar and Hurst (2006) for further elaboration on the question of the definition of leisure.

${ }^{4}$ Although our focus is non-paid time use, the interaction between employment time and non-paid time is too great to ignore. Kimmel and Connelly (2007) found substantial correlations between employment and each of the three non-paid time uses on both weekdays and weekends. In our empirical work for this paper, predicted usual weekly employment time is included as a determinant of non-paid time..
} 


\section{A. Equation Specification}

Our time use equations include economic, demographic, and time/spatial controls. The economic factors include the parent's own wage plus a measure of the spouse's wage. There are two ways to incorporate the spouse's wage in these analyses. First, the spouse's wage can be included directly, as is done in Kalenkoski et al (2006). Or, more consistent with the bargaining literature, we can include the relative wage (we use the wife's wage divided by the husband's wage ${ }^{5}$ ). We opt to include spousal wage information in the latter format because it succeeds in accomplishing two goals simultaneously: relative wages controls for spousal income in a form that permits interpretation of the effect of changes in relative wage as a change in one's own "power" within the couple. ${ }^{6}$ Ceteris paribus, the greater the power that the wife exerts in household decision-making, the more sharing of unpaid household production time within couples is expected. ${ }^{7}$ Thus, we expect higher wife's relative wage to reduce her home production time. The effects on caregiving time and leisure time are ambiguous theoretically.

In addition to own wages and relative wages, both of which enter the time use equations as predicted values, we include predicted measures of the price of child care for children between the ages of zero and 5 and the price of child care for children between

\footnotetext{
${ }^{5}$ Friedberg and Webb(2006) define relative wages as the wife's wage as a share of the total household wage, wife's wage + husband's wage. It is not clear why this would be preferable to the more straightforward wife's wage/husband's wage measure we use. Hersch and Stratton (1994) and Bittman et al. (2003) both use husband's share of total labor income (husband's income/ total couples' income). ${ }^{6}$ Our measure is based on predicted wages which may not be exactly what one wants when thinking about bargaining power, but is preferred when thinking about the relative opportunity cost of time. The difference is important for non-employed wives whose actual wage is zero but have positive predicted wages. In our model, nonemployment is controlled for in the predicted weekly hours of employment. ${ }^{7}$ This statement assumes that the marginal minute of unpaid household production time is a source of disutility.
} 
the ages of 6 and $12 .{ }^{8}$ Like own wage, the price of child care theoretically affects the price of time. When child care must be used in order to participate in a non-paid activity, the opportunity cost of that time is the wage plus the price of child care. When the activity is child caregiving, the effective price of time is the wage minus the price of child care. If the activity can be performed simultaneously with caregiving, then the effective price of time is simply the wage.

Additional economic factors included in our model are both the parent's and spouse's predicted own weekly work hours. Employment time clearly is in competition with non-paid work time. Since many non-paid activities are fungible across the week, weekly employment hours are preferable to diary day employment hours. In addition, weekly employment hours differentiate employed from non-employed individuals which should be an important distinction. ${ }^{9}$ Also note that these spousal weekly employment hours are available in the ATUS for the actual spouse from the accompanying CPS data file, while the daily employment hours on the diary day are not available for spouses.

We include a standard list of demographic controls: age, race dummies (nonwhite, Hispanic), number of children in the ranges of 0-2, 3-5, 6-9, 10-12, and 13-17 plus a dummy variable for the presence of any other (nonspouse) adult in the household. We control for race differences because much previous evidence exists as to differences in caregiving patterns by race. (See for example, Kimmel and Powell, 2006). We expect numbers of children in these various age categories to affect mothers and fathers' time use very differently due to scheduling flexibilities affected by schooling (including

\footnotetext{
${ }^{8}$ See Kimmel and Connelly (2007) for a discussion of the generation of these child care price measures which rely on data from the Survey of Income and Program Participation.

${ }^{9}$ Frazis and Stewart (2005) showed that non-employed men's daily activities look similar to employed men's activities on a non-work day, while for women, non-employed women's daily activities are substantially different from the activities of employed women on non-work days.
} 
preschool) and the possibility of self care for older children. ${ }^{10}$ Time and spatial controls include dummies for observations originating from the 2003 ATUS, summer diaries, and dummies for residence in urban areas or the South.

\section{Section IV: Parents’ Observed Time Use Patterns}

We use data drawn from the 2003 and 2004 surveys of the American Time Use Survey. This new annual, national survey contains a 24-hour detailed time diary for one adult per household. Diaries were collected during each day of the week, including weekends. Family time use is structurally different on the weekend for several reasons, including the unavailability of free "child care” (i.e., public school) and many paid nonparental regular child care arrangements, and the reduced incidence of paid employment. Thus, we stratify our data into separate subsamples comprised of weekday diaries and weekend diaries, the latter including weekday holidays. Our estimating samples are currently married (with spouse present) individuals who have children under the age of 13 living in the household. Merging the 2003 and 2004 surveys yields samples of 1363 fathers with weekday diaries, 1504 fathers with weekend diaries, 1497 mothers with weekday diaries and 1672 mothers with weekend diaries. ${ }^{11}$

For the purposes of estimation, we aggregate many detailed non-paid time activities into three broad categories: household work time, child caregiving time (for one's own children), and active leisure time. ${ }^{12}$ As is shown in Table 1 , the division of

\footnotetext{
${ }^{10}$ We exclude education because it is too collinear with generated wages for men. Kalenkoski et al 2006 also omit education from their time use equation specification.

${ }^{11}$ Sample sizes differ somewhat depending on which model we are estimating. These sample sizes are for the instrumented sample (explained below).

${ }^{12}$ Following Connelly and Kimmel (2007), we define active leisure as all leisure excluding sleep, grooming, and human capital investment time. See Kimmel and Connelly for details concerning the assignment of ATUS activity codes into our general composite categories.
} 
unpaid work time (considering both household production and caregiving) differs dramatically by sex. On average, men engage in 63 minutes of caregiving and 89 minutes of household production on the typical weekday, for a total of 152 minutes of total unpaid work minutes per day. The corresponding figures for women are 159 minutes of caregiving plus 217 minutes of household production, for a total of 376 minutes per day. Including paid work minutes per day in this discussion (477 for men versus 231 for women) yields totals of 629 for men and 607 for women. This represents approximately 10 hours of work per day, and is consistent with the finding of other researchers (see, for example, Bianchi) that has been described in recent weeks in the popular media (see, for example, the NY Times and www.slate.com. ) that total work time for men and women has equalized over the past twenty years. On this one dimension, there has been unequivocal movement towards equality. Tossing active leisure into the mix furthers this observation, as both men and women consume approximately 270 hours of active leisure on the typical weekday.

How different is the average weekend day? For men, their paid work minutes fall to 110 minutes per day while their minutes of household production increase to 200 . Their caregiving minutes increase slightly to 76 minutes per weekend day, and their active leisure rises to 468 minutes per day. For women, there is also a decline observed in paid work minutes, dropping to an average of 48 minutes. Caregiving time, perhaps somewhat surprisingly, falls to 109 minutes while household production time increases to 266 minutes, and active leisure increases to 405 minutes. The fall in caregiving has been found by other researchers as well and seems to be related to which activities are included in caregiving as well as the presence of other potential caregivers on the 
weekends (such as fathers, grandparents, and older siblings). Connelly and Kimmel (2006) examine the timing of activities throughout the day and find that weekday caregiving is highest in early evenings and seems to be related to homework time and pre-bedtime activities, both more likely on weekdays than weekends. Comparing across men and women, note that total non leisure minutes on the weekend for men are 386 while they are 424 for women. This suggests the presence of some weekend gender work inequality, mainly attributable to an extra hour of home production times for mothers.

Means for other demographic and economic factors are presented in Table 2. Due to its larger original sample, approximately 58 percent of our full sample is drawn from the 2003 ATUS survey. Sample characteristics are comparable across weekend and weekday samples, so we describe the weekday samples for both men and women. On average, the men are 38 years old while the women are 36 years old. ${ }^{13}$ About 10 percent of the sample is nonwhite and 15 percent is Hispanic. By sample construction, each household has at least one child under age 13, and the average household has 2 children under age 18. As one would expect, men's hourly wages are higher than women's. What is not clear is why the relative wage predicted from the mother's sample is lower than that predicted by the father's sample, given that the spousal wage measure used here is that reported on the CPS file accompanying the ATUS file. The weekly hours of employment for both men and women predicted from the two samples are similar, with men predicted to be employed about 45 hours a week and women about 15 hours per week.

\footnotetext{
${ }^{13}$ This age discrepancy reflects the fact that, by design, the sample is comprised of married persons with children under age 13. Men tend to have children at an older age than women.
} 


\section{Section V: Econometric Methodology}

As described earlier, our goal is to estimate three time use equations for mothers and for fathers. To account for the possibility of zero time engaged in some time uses, we estimate the observed time choices using a Tobit model. To account for the competition between time uses on any given day, we estimate a three equation Seemingly Unrelated Regression (SUR) Tobit model for mothers and then for fathers. ${ }^{14}$ The three equation SUR strategy permits correlation of error terms across an individual's time usages. See Kimmel and Connelly (2007) for a more detailed description of this econometric methodology. ${ }^{15}$

For studying the effect of spousal variables on non-paid time use, the ATUS survey design reflects a near fatal flaw. ${ }^{16}$ While the sampling unit is the household, time diary information is collected for only one person per household. Thus, although we do know a great deal of demographics about one's spouse, we lack the detailed time use information for the same day, crucial information for the study of couples' joint time use. We attack this problem in three ways. Our first approach is to restrict our empirical specifications to incorporate the actual spousal information available in the accompanying CPS data files. For each individual with a time diary, the accompanying CPS file contains the spouse's reported usual weekly hours worked for pay and weekly earnings. From this information, a measure of the spouse's hourly wage can be constructed. Using this information, we can estimate individual time use equations for

\footnotetext{
${ }^{14}$ We have not attempted to estimate the husband and wife time use equations together since we do not expect the correlation across husband's and wife's time use to be maintained through either of our methods to predict spousal time.

${ }^{15}$ Kalenkoski et al. (2006) also use a SUR Tobit. Like them, we use the aML statistical software package for our estimation.

${ }^{16}$ On the other hand, the ATUS provides spouses wage and employment hours, variables not available in the previous U.S. time diaries.
} 
leisure, unpaid household production, and caregiving in which controls are included for the spouse's work hours, the relative wage (defined as the woman's wage divided by the man's wage throughout), and the spouse's usual weekly employment hours. This permits us to estimate the effect of these measures on time choices. Both the spouse's weekly employment hours and the spouse's wage are instrumented through standard first stage procedures to reduce the problem of endogeneity of actual employment hours and wages with non-paid time use.

This first methodology has the advantage of relying on the actual spouse's information available in the ATUS. However, its drawback is that we cannot examine the full implied household decision-making process; namely, that one's time devoted to the production of household services is made jointly with the spousal contribution to the production of the same household services. This view posits that a household has some total of household services to produce, and the husband/wife team divide the total required time input between themselves, or, more generally, that a husband and wife's time in an activity is affected by the other's time spent in that activity. Thus, it could be that the husband and wife divide up a fix set of tasks or that more time spent cleaning by the wife means that the husband also is expected to clean more. In either case, we would like to examine the wife's time devoted to household production, for example, while controlling for the husband's engagement in the same activity.

Were time diaries for both the husband and wife in each married couple household available, then we could approach estimation of this household model in either of two ways. First, we could examine the wife's caregiving time determined, in part, by the husband's caregiving time; i.e., the husband's caregiving time would be included as a 
regressor in the wife's caregiving equation. Of course, the husband's caregiving time would be endogenous, thus necessitating instrumentation. Alternatively, we could examine the share of total household caregiving time, for example, contributed by the wife. (See, for example, Presser 2003; pg. 115.) Focusing on shares of time abstracts from the issue of level, focusing instead on the relative contribution of the two spouses to their joint home production or leisure time use. Using the share of time as the dependent variable does not reduce the data needs of the exercise since one's spouse's time use in the activity is needed to construct the share. ${ }^{17}$

For either of these two approaches to estimating the effect of spouse's time on the other spouse's time use, the piece of information missing from the ATUS is the spouse's actual minutes in caregiving, household production, and active leisure. We use two strategies to address this data deficit: out-of-sample prediction and matching. These solutions rely on the fact that while spousal time diary information is unavailable, the ATUS data do contain much detail about the spouse, such as age, education, number of children, usual hours worked, etc. We use the available information on the actual spouse plus the fact that we have time diaries for both husbands and wives (not from the same household) to construct the missing daily spousal time in active leisure, child caregiving and home production. Each of the two strategies offers pros and cons in terms of providing us with usable imputed spousal time variables. Their strengths and weaknesses are discussed below.

The “out-of-sample prediction” methodology is familiar to many readers. It is a variant of the strategy that is usually used to construct wages for nonworkers. In this

\footnotetext{
${ }^{17}$ We define the share of each non-paid time use as the wife's minutes in each of three activities divided by the total of the wife's plus the husband's total minutes in each activity.
} 
case, we use a sample of husbands' time diaries and estimate reduced form tobit equations for each of the three non-paid time uses using characteristics of the father and his wife as regressors. We then calculate predicted husband's time use for each mother in our mothers sample by using the estimated coefficients from the reduced form tobits and the characteristics of the mother and her actual spouse. Similarly, we use a sample of mothers' time diaries and estimate reduced form tobit equations for each of the three nonpaid time uses using the mothers' characteristics and husband characteristics. We then predict the wife's time use for the father's time diary sample. This results in generated time use measures for true spouses. The advantage of this strategy is that it uses the full sample of observations in order to estimate the coefficients of the determinants of time spent on the three non-paid activities and the actual spouse's characteristics exactly. The disadvantage is that the covariances among the three time uses of the spouse are lost since each is a predicted value based on estimated coefficients.

The matching approach we use relies on a strategy that has gained prominence in the program evaluation literature. Dehejia and Wahba (2002) describe the propensity matching technique in great detail. The idea is to "marry" a wife/ mother with a time diary to a husband/father with a time diary based on the similarity of their characteristics including the characteristics of their actual spouses. Thus, we "marry” a 30 year old woman with a time diary who has a 34 year old husband and a one year old child to a 34 year old man with a time diary who has a 30 year old wife and a one year old child. With this match, we assign all three non-paid time uses from the husband's file to his new “spouse's” file. These actual time uses of her "matched spouse” become the predicted time uses of her actual spouse. This method has the advantage of maintaining the 
variance in time uses and the covariance among the three spousal time use, but the disadvantage of being based on a single person's data. Appendix B explains the matching procedure in detail.

Producing spousal time use information either via out-of-sample prediction or by relying on synthetic spouses (i.e., matching on observed characteristics) both have the drawback of losing the covariance one would expect to be present in actual spouse time measures as household level unobservables are expected to affect both spouses' time use on a given diary day. For example, if Mondays are soccer days for mother A's daughter and her husband does the soccer driving, she would have extra home production on Mondays and her husband would have extra caregiving. But if, at her matched "husband's" house, Monday is his bowling night, it looks like no one in the home of mother A is doing any caregiving, her "spouse" has lots of leisure and she is doing a lot of home production. The only solution to the missing covariance problem is to have actual data on couples as in the British or Australian time use studies. A task for future research is to evaluate the importance of the unobserved covariances in couples' time use compared to the effects of the observables.

Another disadvantage of the ATUS that contributes to difficulties in "creating" spousal time use information is that the ATUS time diary covers just a single 24 hour period. To the extent that researchers are interested in "typical" household time use, a single 24 hour snapshot may fail to portray sufficient nuances. This single day drawback likely is more of a problem for tasks that can be moved from day to day or from weekday to weekend day with ease. A good example is laundry. In some families, the husband is in charge of all the laundry, but may do it all on Sundays. Thus, he may appear to have 
little to no contribution to unpaid household production for six days of the week, but if our time diaries happen to catch him on his laundry Sunday, then he appears active in household production. This fungibility is less extensive in child caregiving activities, thus, the caregiving estimates probably suffer less from the single diary day problem.

\section{A. Estimation Summary}

In sum, we have approached the question of the role of spouses in parents' time use with three distinct methodologies. We have described these different methodologies above, but for the sake of clarity, we list them below in summary fashion. Note that we estimate time use equations for mothers and fathers for three uses of time: active leisure, unpaid household production, and caregiving. Additionally, we estimate equations separately for weekdays versus weekends. The three estimation approaches (including the two alternatives for the second and third methodologies) are listed below.

1. Parent's level of time use with observed (thus limited) spousal information

a. Table 4a: moms and dads, weekday (6 columns)

b. Table 4b: moms and dads, weekend (6 columns)

2. Parent's level of time use with spouse's time use included as a regressor in each of three time use equations.

a. Measure of spouse's time use is generated via out-of-sample prediction.

i. Table 5a: moms and dads, weekday (6 columns)

ii. Table 5b: moms and dads, weekend (6 columns)

b. Measure of spouse's time is generated using the "matched" spouse approach.

i. Table 6a: moms and dads, weekday (6 columns) 
ii. Table 6b: moms and dads, weekend (6 columns)

3. The wife's share of the parents time use

a. The wife's portion of the couple's total time in each activity is constructed via out-of-sample prediction.

i. Table 8a: moms and dads, weekday (6 columns)

ii. Table 8b: moms and dads, weekend (6 columns)

b. The wife's portion of the couple's total time in each activity is constructed using the "matched" spouse approach.

i. Table 9a: moms and dads, weekday (6 columns)

ii. Table 9b: moms and dads, weekend (6 columns)

\section{Section VI: Empirical Results on the Level of Non-Paid Time}

Prior to our estimation of the time use models, we completed several instumenting equation estimations to construct the necessary generated regressors for own usual weekly paid work hours, spouse’s usual weekly paid work hours, own log wage, and spouse's log wage, the price of child care for children aged 0 to 5, and the price of child care for children aged 6 to 12. Full results from these preliminary regressions will be presented in the next draft of this paper, as will a discussion of identification. Most important for the current draft is to note the omission of education as a regressor in the time use equations. Education is too collinear with our generated wage measures for men to be included as a separate regressor in these equations.

Results from a set of baseline regressions run for mothers and fathers in which spousal information is excluded are available from the authors. As expected, these 
results for mothers mirror those found in Kimmel and Connelly (2007). That is, caregiving behaves unlike leisure or household production in its responses to child care prices and wages. In fact, the own wage effect on caregiving is positive, as was found for paid work minutes. For fathers, a similar result is found for caregiving, namely a positive own wage effect is found for both weekdays and weekends.

\section{A. Role of Spousal Economic Factors}

Tables 3a and 3b present a summary of findings regarding the role of spousal economic factors in mothers' and fathers' time use choices respectively. Note that the key spousal measures in these regressions are the predicted relative wage and the spouse's predicted usual weekly work hours. Additionally, in the time use equations using either "out of sample prediction” or matching approaches, an instrumented measure of the spouse's time choice for the same activity (i.e., leisure, caregiving, then household production) is included as an additional regressor.

Actual Spouse Model: Probably the most “pure” estimates of the role of spousal factors on own time choices are the results that use the actual spouse's weekly work hours and own relative wage. These effects are "pure" in the sense that they do not rely on synthetic spouse information or out-of-sample prediction. They are also the most comparable to the results of previous studies. Starting with leisure time, the mother has more minutes of leisure on weekdays and weekends when her husband works more hours for pay. This may represent a pure income effect since husband's earnings is often thought of as a quasi-exogenous variable in the determination of a wife's labor/leisure tradeoff. While her bargaining power in the household (as proxied by her relative wage) 
has no impact on her leisure time during the week, it is associated with increased leisure minutes for her on the weekend. A father's leisure time is not responsive to his wife’s paid work hours or her relative wage. These findings mirror the findings of Kooreman and Kapteyn (1987).

Caregiving in a family context appears complicated. Mothers’ caregiving minutes are not responsive to their husbands' paid work hours nor her relative wage, but fathers' caregiving minutes are affected by their wives’ economic factors. During the week, husbands spend more minutes in caregiving when they have wives who work more hours for pay or when their wives earn a higher proportion of the households' total earned income. However, on weekend days, while husbands still "pick up the slack” from the wives increased paid work effort, they actually perform fewer caregiving minutes when married to a wife who has a higher relative wage. This flip in the sign of relative wage effect for fathers may suggest a complex bargaining power effect, namely, that the wife with higher relative wages gets more help from the husband during the week to assist in non-fungible caregiving activities, but during the weekend, her greater bargaining power buys her more time with her children. This is consistent with the finding of a significantly positive own wage effect for mothers, as is found throughout the various estimations.

Household production appears entirely nonresponsive to observed spousal characteristics, either on weekdays or on the weekend, for mothers or fathers. Note however, that this finding is produced with diary data for a single 24-hour period, which as discussed earlier, may be most problematic for household production. 
Time Models Including Spouses Daily Time in the Activity: The results from our second set of analyses, in which the spouse's minutes in the specific activity is included as a regressor created from either an “out of sample prediction” or from matching appear next in Tables 3a and 3b. Overall, the predicted spousal time in the same activity contributes little to the parents' time use choices. Results based on the matched spouses approach are never significant. However, using out-sample-prediction, mothers whose husbands have more leisure time also have more leisure time on weekdays, indicating they may be spending time together, but on the weekends the effect is reversed. On weekends, wives with husbands who have more leisure minutes tend to have fewer minutes of leisure themselves.

Regarding caregiving, it appears that mothers are relieved of some of their weekday caregiving responsibilities by husbands taking over some of the duties; the coefficient for husband's minutes of caregiving is negative and significant for the "out of sample prediction” but not for the matching model. On the weekends, none of the spouse variables are significant for either specification.

Finally, turning to household production, wives devote more minutes to unpaid household work on the weekends when their husbands contribute more minutes when husband's time in household production is predicted with the "out of sample prediction" strategy. This makes sense if one considers the husbands' participation in household production as a signal of higher household standards or if women whose husband engage in housework need to “do gender” by doing more housework themselves. (Bittman et al, 2003) 


\section{B. Role of Own Economic Factors in Minutes of Time Models}

Because we have produced three different sets of estimates for weekdays and three for weekends for both mothers and fathers, it is difficult to summarize them all concisely here. However, there are a handful of notable findings. An individual's own wage level is almost never significant in the choice of the amount of leisure time and home production time, for men or women, on weekdays and weekends. On the other hand, the effect of own wage level on caregiving is mostly positive for both mothers and fathers, on both weekdays and weekends. This matches the positive own wage effect found in Kimmel and Connelly (2007) in their research that examined mother's time use choices without consideration of the role of spouses. Kalenkoski et al. (2006) found similar positive effects of education (proxying wages) in the UK and Sousa-Poza et al. (2001) found a positive wage effect for caregiving for women in Switzerland.

The other included economic factors that affect the value of time are the two measures of child care prices, the first for pre-kindergarten aged children and the second for school-aged care. One might expect that higher child care prices, ceteris paribus, would be associated with more own caregiving minutes for both mothers and fathers. This expected positive (and significant) coefficient is found in several cases, most notably for the pre-k child care price for mothers on weekdays and fathers on weekends. In two sets of results, a higher child care price for school-aged children is associated with fewer maternal weekday caregiving minutes. Since the price of school-age child care is set to zero for families without school age children, the negative effect may simply be picking up some of the differential in minutes of child care between pre-k and school age children. 
The final own economic factor included in the analysis of time in non-paid activities is the own predicted usual hours of paid employment. For women, the effect on weekday time use of more weekly hours of paid employment is mostly negative; women with more hours of paid employment have fewer minutes of weekday leisure, fewer minutes of weekday caregiving and fewer minutes of weekday home production time. However, more weekly hours of paid employment have no effect on women's weekend non-paid time and no effect on men's daily non-paid time on weekdays or weekends.

\section{C. Role of Demographics, Time and Spatial Controls}

Probably the most notable findings among this set of variables are the role of children and the importance of summer. It is comforting to note that based on the self reported categorization of child caregiving time versus home production and leisure activities, both mothers and fathers tend to devote more minutes to caregiving when there are very young children in the household. Additionally, both parents devote fewer minutes to caregiving in the summer time, and mothers experience fewer leisure minutes when they have more children between the ages of 10 and 12. Apparently, all that driving around takes its toll.

Older mothers consistently spend more time in home production on both weekdays and weekends. Older fathers also spent more time in home production on weekdays. The other demographic variables have no statistically significant effect consistently across specifications, although the size and signs of the coefficients are similar. 


\section{Section VII: Empirical Results for the Wife's Share of Time}

As we discussed above, the level of time use for men and women may not capture fully the division of household labor. If one couple maintains a higher standard of cleanliness than another, the husband in the first couple will be spending more time in home production even if he is doing a smaller share of the total work. Presser (2003) and Goldscheider and Waite (1991) both suggest that a better measure of couple’s dynamics may be the wife's share of home production. Hersch and Stratton (1994) estimate both level and share equations for housework. Given the argument in Kimmel and Connelly (2007) that child caregiving must be examined apart from both home production and leisure, we are also interested in the effect of economic and demographic variables on the wife's share of caregiving and leisure.

\section{A. Role of Spousal Economic Factors}

As the spouse's time use must be used to construct our measure of the dependent variable, the wife's share of total household time in that activity, we cannot estimate share equations with the actual ATUS time diary respondent data alone. Instead, we again use our two methods to predict the spouse's time use. Each model is estimated separately for women and men but the reader must be careful to recall that the dependent variable is defined consistently as the wife's share of total couple time use and the relative wage is defined consistently as the wife's predicted wage divided by the husband's predicted wage. If bargaining power is an important determinant of the share of time devoted to non-paid activities, then increasing relative wages should decrease the share of home production and maybe childcare that the wife performs and increase her 
share of leisure. This hypothesis is based on the notion that home production (and maybe child caregiving) is a source of disutility, leisure is a source of utility, and relative wages are a measure of bargaining power. The sign of the relative wage effect should be the same whether the demographic characteristics are coming from the mother or the father. Tables 7a and 7b summarize the results of the spousal variables on the wife's share of total household non-paid time. The full sets of coefficients are presented in Tables 8a, 8b, 9a and 9b. The only instance where we see any of these hypothesized relative wage effects is for weekend home production generated with "out of sample prediction” using the fathers' sample. In this instance, a higher relative wage of the wife reduces her share of weekend home production time. Mostly, however there seems to be no effect of relative wage on the share of home production performed by the wife or the share of leisure. On the other hand, the effect of higher relative wages on caregiving is strongly positive and is robust across prediction strategy and weekday versus weekend. ${ }^{18}$ The positive coefficient implies that even controlling for the level of the mother's own wage (which also has significant positive effects on the share of caregiving time, see Tables 9a and 9b but not in Table 8a and 8b) mothers with higher relative wages perform a larger share of the total household child caregiving. It is not clear why this should be the case although it does not surprise us that caregiving is not behaving like either home production or leisure. It may be that mothers with higher relative wages have the “power” to choose activities they enjoy, including caregiving. An alternative explanation that can be examined with the ATUS is that these women with high relative wages are

\footnotetext{
${ }^{18}$ These positive effects of relative wage on the wife's share of caregiving are also robust to the specification of the wage equation and the time use equations.
} 
employed at times of day that are less likely to compete with prime time caregiving. (See, for example, Connelly and Kimmel 2006.)

Based on the tradeoffs implicit in a daily time constraint, we also hypothesized that having one's husband work more hours during the week would increase the share of home production and caregiving women performed, with no clear prediction about the share of leisure. Tables 7a shows no effect of husband's weekly employment hours on leisure and home production. The effect on child care is the reverse of the prediction, increased husband's weekly employment hours lead to a decrease in the wife's share of child caregiving time.

Having one’s wife work more hours during the week was expected (if anything) to decrease the wife's share of home production and caregiving. Tables $7 \mathrm{~b}$ confirms this prediction for child caregiving time on weekdays using both techniques for calculating shares. Caregiving on weekends and home production on both weekdays and weekends also are shown to be significantly negative using the matching technique.

\section{B. Role of Own Economic Factors in Share Models}

The effect of own wage level on the wife's share of non-paid time does not yield any strong patterns across the equations estimated. For leisure and home production, the effects of own wage mostly are insignificant for both mothers and fathers. For the weekday share of caregiving using mothers characteristics, the matched strategy and the “out of sample prediction” methodology yield coefficients with the opposite sign for her own wages.

Mothers who are employed more hours per week consistently have a lower share of all non-paid time uses while increased employment hours of fathers seldom seems to 
affect the share of non-paid household time they perform. We had expected father's employment hours to increase the wife's share, but this is only the case for weekday caregiving using the "out of sample" prediction strategy.

\section{C. Role of Demographics, Time and Spatial Controls}

We do not have strong priors about the expected effects of the demographic, time, and spatial controls on the wife's share of time use. In the "out of sample prediction" model, the number and ages of children are found to have significant effects on the wife's share of caregiving. Younger children reduce the wife's share while older children increase the wife's share. With the matched model, almost none of these effects are significant. Recall that the "out of sample prediction" methodology provides a predicted spouse's daily minutes in caregiving while the matched model provides the actual daily minutes in caregiving from the matched "spouse". Could this explain the difference in the level of estimation precision between the two models? If we believe the "out of sample prediction" results, how can we understand the finding that the wife's share increases with age of the child? Recall that the actual requisite amount of caregiving time is greater for younger children, so it appears that when there is more caregiving to be done, fathers participate more but when there is less to be done, mothers continue to provide the care and fathers' care time is reduced.

VII. D. Reliability of the Matched Spouse and "Out of Sample Prediction" Methodologies

The effect of the number and age of children on the wife's caregiving share is not the only place where the matching and "out of sample prediction" methods yield different results. Even in Table 1, we see substantial differences in the mean shares depending on which method we used to create the share variable. In addition, there are numerous 
coefficients in the men's and women's share models that would be expected to have the same sign (or the opposite sign) and they do not. Thus, it is not clear whether either approach is sufficiently reliable to be pursued in future research. One way to address this question is to use a similar set of strategies on data that has time diaries for both the husband and the wife. We plan to do this with British, Australian and German time use data in a subsequent paper.

\section{Section VIII: Concluding Remarks}

Overall, our results reveal that spouses play very little role in parents' time use choices. In home production, typically the focus of research due to women's continuing dominance despite substantial changes in women's labor supply, the relative wage has no effect on the level of home production that either men or women perform on either weekdays or weekends. For leisure and caregiving, the results for the relative wage are also statistically insignificant in most of the specifications. Certainly, no clear pattern emerges.

The spouses' usual weekly work hours has no effect on home production time choices. Mothers' leisure time is positively related to husbands' work hours when the variable comes from their actual husband but not when it is predicted out of sample or contributed by a matched spouse. For caregiving time, increased spouses' weekly work hours seem to increase weekday caregiving of the other spouse, but not weekend caregiving.

Finally, in terms of the spouse's time in the same activity, we find very little of substance. Using a matched spouse never yields a statistically significant finding, while 
using a composite "out of sample prediction” produces a significant substitution effect for weekday caregiving for women and a significant complementarity effect for weekday leisure for women. On the weekend, women's leisure decreases when their predicted husband's leisure increases but their home production time increases when their predicted husbands’ time increases.

Spousal variables play a more meaningful role in the wife's share of time use, which makes sense since the dependent variable includes both the husband and the wife's time use. However, no clear pattern emerges and our two estimation strategies yield very different results except in terms of caregiving time where higher relative wages of mothers to fathers is predicted to increase the share of caregiving done by mothers on both weekdays and weekends. Both strategies should be strong predictors of the systematic parts of time use and wages since the ATUS offers much information that we use in both estimation strategies. The sensitivity tests of the matching sample revealed that the match was successful in recreating means for 10 strata on each of the variables that the two samples held in common. As such, two hypotheses remain: either the results we have presented are true, in which case the conclusion must be that spousal characteristics matter little as a determinant of individual time use, or all that matters is the unobservables which are lost in both of the estimation strategies we implement. The hypothesis that spousal characteristics do not matter is credible given the plethora of results showing little explanatory power of observables on husbands' housework time, the recent results of Blau and Kahn (2005) that husband's characteristics play a much reduced role in determining wages of married women in 2000 versus 1980, and the 
results of Friedberg and Webb (2006) who found very small effects of relative wages on narrow category time usages from the ATUS. 


\section{References}

Aguiar, Mark and Erik Hurst. 2006. "Measuring Trends in Leisure: The Allocation of Time Over Five Decades,” NBER Working Paper No. 12083 (March).

Alvarez, Begona and Daniel Miles. 2003. “Gender Effect on Housework Allocation: Evidence from Spanish Two-Earner Couples,” Journal of Population Economics, $16,227-242$.

Bianchi, Suzanne, Lynn Casper, and Roselind King, eds. 2005. Work, Family, Health and Well-Being. New York: Laurence Erlbaum Associates, 600 pages.

Bittman, Michael, Paula England, Liana Sayer, Nancy Folbra and George Matherson. 2003. "When Does Gender Trump Money? Bargaining and Time in Household Work,” American Journal of Sociology, 109(1), 186-214.

Blau, Francine and Laurence Kahn. 2005. "Changes in the Labor Supply Behavior of Married Women: 1980-2000,” NBER Working Paper No. 11230 (March).

Blundell, Richard and Thomas McCurdy. 1999. "Labor Supply: A Review of Alternative Approaches,” in Handbook for Labor Economics, Vol. 3A, ed. Orley Ashenfelter and David Card, Amsterdam: Elsevier Science.

Browning, Martin and Pierre-Andre Chiappori. 1998. “Efficient Intra-household Allocations: A General Characterization and Empirical Tests,” Econometrica, 66, 1241-78.

Chiappori, Pierre-Andre. 1988. “Rational Household Labor Supply,” Econometrica, 56, 63-90.

Chiappori, Pierre-Andre, Bernard Fortin and Guy Lacroix. 2002. "Marriage Market, Divorce Legislation and Household Labor Supply,” Journal of Political Economy, 110(1), 37-72.

Connelly, Rachel and Jean Kimmel. 2006. “The Impact of Nonstandard Work on Caregiving for Young Children,” unpublished manuscript prepared for presentation at the 2006 SOLE meeting.

Dehejia, Rajeev and Sadek Wahba. 2002. "Propensity Score-Matching Methods for Nonexperimental Causal Studies,” Review of Economics and Statistics, 84(1), 151-161.

Devereux, Paul. 2004. “Changes in Relative Wages and Family Labor Supply,” Journal of Human Resources, 39(3), 696-722. 
Fortin, Bernard and Guy Lacroix. 1997. "A Test of the Unitary and Collective Models of Household Labour Supply,” Economic Journal, 107, 933-955.

Frazis, Harley and Jay Stewart. 2005. “What Do Male Nonworkers Do? Evidence from the American Time Use Survey.” Working Papers 371, U.S. Bureau of Labor Statistics.

Friedberg, Leora and Anthony Webb. 2006. “The Chore Wars: Household Bargaining and Leisure Time,” unpublished manuscript (August).

Goldscheider, Frances K. and Linda J. Waite. 1991. New Families, No Families? Los Angeles: University of California Press, 303 pages.

Graham, John W. and Carole A. Green. 1984. "Estimating the Parameters of a Household Production Function with Joint Products,” The Review of Economics and Statistics Vol. 66, No. 2 (May), pp. 277-282.

Halberg, D. 2003. "Synchronous Leisure, Jointness, and Household Labor Supply,” Labour Economics, 10, 185-202.

Hamermesh, Daniel H. 2000. “Togetherness: Spouses’ Synchronous Leisure and the Impact of Children,” NBER Working Paper W7455.

Hamermesh, Daniel H. 2007. “Time to Eat: Household Production Under Increasing Income Inequality,” forthcoming American Journal of Agricultural Economics.

Hausman, J and P. Ruud. 1984. "Family Labor Supply with Taxes,” American Economic Review, 74, 242-48.

Hersch, Joni and Leslie Stratton. 1994. "Housework, Wages and the Division of Housework Time for Employed Spouses,” American Economics Review, 84(2), 120-125.

Hersch, Joni and Leslie Stratton. 2002. “Housework and Wages,” The Journal of Human Resources, 37 (1), 217-229.

Hersch, Joni. 2003. “Wages, Time Use, and Household Decision Making,” unpublished manuscript (October); downloaded March 5, 2005 http://www.fundacionareces.es/PDF/hersch.pdf.

Jenkins, Stephen and Lars Osberg. 2005. "Nobody to Play with? The Implicatons of Leisure Coordination,” in The Economics of Time Use, eds. Daniel Hamermesh and Gerard Pfann, Amsterdam: Elsevier, 113-145.

Kalenkoski, Charlene, David Ribar, and Leslie Stratton. 2006. "Parental Child Care in Single Parent, Cohabiting, and Married Couple Families: Time Diary Evidence 
from the United Kingdom,” American Economic Review papers and proceedings, May.

Killingsworth, Mark. 1983. Labor Supply. Cambridge, England: Cambridge University Press.

Kim, Jongsoong and Lydia Zepeda. 2004. "When the Work is Never Done: Time Allocation in US Family Farm Households,” Feminist Economics, 10(1), 115139.

Kimmel, Jean and Rachel Connelly. 2007. "Mothers’ Time Choices in the United States: Caregiving, Leisure, Home Production and Paid Work," The Journal of Human Resources, forthcoming.

Kimmel, Jean and Lisa Powell. 2006. "Nonstandard Work and Child Care Choices of Married Mothers.” Eastern Economic Journal Vol. 32, No. 3 (Summer), pp. 397419.

Kooreman, Peter and Arie Kapteyn. 1987. "A Disaggregated Analysis of the Allocation of Time within the Household,” Journal of Political Economy, 95(2) (April), 223-249.

Lam, David. 1988. "Marriage Markets and Assortative Mating with Household Public Goods,” Journal of Human Resources, 23, 462-487.

Lundberg, Shelly. 1988. "Labor Supply of Husbands and Wives: a Simultaneous Equations Approach,” Review of Economics and Statistics, 70, 224-235.

Lundberg, Shelly and Robert Pollak. 1993. "Separate Spheres Bargaining and the Marriage Market,” Journal of Political Economy, 101 (6), 988-1010.

Lundberg, Shelly, Robert Pollak and Terence Wales. 1997. "Do Husbands and Wives Pool Resources: Evidence from the UK Child Benefit,” Journal of Human Resources, 32(3), 463-480.

Manser, Marilyn and Murray Brown. 1980. "Marriage and Household Decision Making: a Bargaining Analysis.” International Economic Review, 21, 31-44.

McElroy, Marjorie and Mary Horney. 1981. "Nash-bargained Decisions: Toward a Generalization of the Theory of Demand," International Economic Review, 22(2), 333-349.

Presser, Harriet B. 2003. Working in a 24/7 Economy, New York: Russell Sage Foundation, 267 pages. 
Ransom, M. R. 1987. "An Empirical Model of Discrete and Continuous Choice in Family Labor Supply,” Review of Economics and Statistics, 59, 465-72.

Solberg Eric J. and David C. Wong. 1992. "Family Time Use: Leisure, Home Production, Market Work, and Work Related Travel,” The Journal of Human Resources, 27(3)(Summer), 485-510.

Sousa-Poza, Alfonso, Hans Schmid, and Rolf Widmer. 2001. "The Allocation and Value of Time Assigned to Housework and Child-Care: an Analysis for Switzerland,” Journal of Population Economics, 14, 599-618.

Thomas, Duncan. 1990. “Intra-Household Resource Allocation: An Inferential Approach,” Journal of Human Resources, 25(4), 635-664.

Van den Brink, Henriette Maassen and Wim Groot. 1997. "A Household Production Model of Paid Labor, Household Work and Child Care,” De Economist Vol. 145 No. 3, pp. 325-343. 


\section{Appendix A: Theoretical Model}

We present a summary of the theoretical model here. Note that the i subscript equals $\mathrm{m}$ for the mother and $\mathrm{f}$ for the father. In this way, the model is generalized for spouse $\mathrm{i}$. $\max U_{i}=U_{i}\left(t_{L i}, C S, G\right)$ subject to the budget, time and production constraints denoted below.

$\mathrm{P}_{\mathrm{X}} \mathrm{X}+\mathrm{P}_{\mathrm{cc}} \mathrm{t}_{\mathrm{cc}}+\mathrm{P}_{\mathrm{CX}} \mathrm{CX}=\Sigma \mathrm{w}_{\mathrm{i}} \mathrm{t}_{\mathrm{em}, \mathrm{i}}+\mathrm{V}$

where: $\mathrm{X}$ : purchased intermediate goods (with price equal to $\mathrm{P}_{\mathrm{x}}$ )

CX: purchased child goods (with price equal to $\mathrm{P}_{\mathrm{cx}}$ )

Spousal time constraint: $T_{\mathrm{i}}=\mathrm{t}_{\mathrm{em}, \mathrm{i}}+\mathrm{t}_{\mathrm{hp}, \mathrm{i}}+\mathrm{t}_{\mathrm{cc}, \mathrm{i}}+\mathrm{t}_{\mathrm{L}, \mathrm{i}}+\mathrm{t}_{\mathrm{s}, \mathrm{i}}$

where em: paid employment

cc: caregiving

hp: household production

L: active leisure

s: all other time uses

Child Time Constraint: $\mathrm{CT}=\mathrm{t}_{\mathrm{mcc}}+\mathrm{t}_{\mathrm{fcc}}+\mathrm{t}_{\mathrm{cc}}+\mathrm{t}_{\mathrm{scc}}$ )

where scc indicated secondary child care

Household production function: $G=G\left(t_{m h p}, t_{f h p}, X ; \theta\right)$

Child Services Production Function: $\mathrm{CS}=\mathrm{CS}\left(\mathrm{t}_{\mathrm{mcc}}, \mathrm{t}_{\mathrm{fcc}}, \mathrm{t}_{\mathrm{cc}}, \mathrm{CX} ; \phi\right)$

where $\theta$ and $\phi$ are efficiency parameters 


\section{Appendix B: Propensity Matching}

The matching process we used is a propensity matching strategy with replacement. The idea of any matching strategy is to replace the missing data with actual data from another respondent. The respondent who is missing data is matched on observable characteristics with a similar respondent who have the missing variable(s). Propensity score matching is a strategy that allows us to "match" on a large number of dimensions which increases the precision of the exercise. (Dehejia and Wahba 2002) To create the propensity score, which serves the role of summarizing in a single number all the information we have on all the observables, the father and mother time diary sample are combined and we ran a logit to predict whether the data comes from the male or female sample. Following the procedure outlined in Dehejia and Wahba (2002), we began with a linear specification of age of both spouses, education of both spouses, race of both spouses, the usual employment hours of both spouses, the number of children and the presence of other adults in the household, the diary day and whether the diary was collected in the summer. We then added quadratic and cubic terms until the t-tests of the means of the 10 strata within the data showed no difference between the "matched" variables and the actual variables. In our case, there were a great number of variables the two data sets held in common, so the quality control tests were substantial.

The actual matching was done using the nearest neighbor criterion with sample replacement. The nearest neighbor criterion links each time diary respondent to the time diary respondent of the opposite sex with the closest propensity score. ${ }^{19}$ We used a oneto-one match with replacement such that one husband record might be linked to more

\footnotetext{
${ }^{19}$ The propensity score is the dot product from the logit estimation beta vector and the actual values of each respondent's $\mathrm{X}$ variables.
} 
than one wife record if his propensity score is closer to each wife than any other potential husband's score. Dehejia and Wahba (2002) explored the difference between matching with replacement or without and showed pros and cons of each approach.

Once the checking is completed, the variables supplied by the matched spouse were the three non-paid time levels, his or her predicted natural log of wage, and his or her predicted usual hours of weekly paid employment. 
Table 1: Means, Standard Deviations and Sample Sizes for Non-Paid Time and Wife's Share of Time

Mothers

Weekday Weekend

Minutes of active

Leisure

Minutes of child

caregiving

Minutes of home

production

Minutes of

employment

Sample size

Mothers sample

Wife's share of active leisure

$$
\begin{aligned}
& \text {--mean } \\
& \text {--sd } \\
& \text {--sample size }
\end{aligned}
$$

Wife's share of caregiving

Wife's share of home production

$\begin{array}{rr}270.56 & 404.78 \\ (150.34) & (188.77)\end{array}$

159.32

(138.01)

109.72

(129.62)

217.41

(164.95)

266.33

(171.06)

231.06

(246.65)

47.86

(139.50)

1497

1672

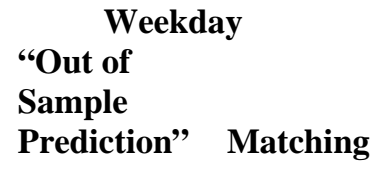

\section{Fathers}

Weekday Weekend

$\begin{array}{rr}263.66 & 468.06 \\ (157.96) & (207.44)\end{array}$

$62.94 \quad 76.40$

(86.18) (116.53)

$89.34 \quad 200.03$

(118.27) (178.48)

$477.76 \quad 110.10$

(214.08) (212.69)

$1363 \quad 1504$

\section{Weekend \\ “Out of \\ Sample \\ Prediction” Matching}

$$
\begin{array}{rrrr}
0.4598 & 0.4229 & 0.4405 & 0.5087 \\
(0.1438) & (0.1929) & (0.1261) & (0.1861) \\
1447 & 1487 & 1602 & 1666
\end{array}
$$

$0.7948 \quad 0.6735$

(0.2323) (0.3361)

$1350 \quad 1434$

$$
\begin{array}{rr}
0.6593 & 0.6079 \\
(0.2386) & (0.2978) \\
1447 & 1475
\end{array}
$$

$0.6762 \quad 0.5720$

$\begin{array}{ll}(0.3172) & (0.3865)\end{array}$

$1362 \quad 1518$

$$
\begin{array}{rr}
0.5311 & 0.6617 \\
(0.1972) & (0.2769) \\
1602 & 1653
\end{array}
$$

\section{Fathers sample}

Wife's share of active leisure

$\begin{array}{rr}0.5499 & 0.5596 \\ (0.1452) & (0.1939) \\ 1387 & 1355\end{array}$

$$
\begin{array}{rr}
0.4889 & 0.6669 \\
(0.1307) & (0.3581) \\
1529 & 1384
\end{array}
$$

Wife's share of caregiving

$$
\begin{array}{rr}
0.7811 & 0.6716 \\
(0.2258) & (0.3406) \\
1386 & 1281 \\
& \\
0.7751 & 0.7383 \\
(0.2044) & (0.2654) \\
1387 & 1343
\end{array}
$$

$$
\begin{array}{rr}
0.7080 & 0.5839 \\
(0.3035) & (0.2934) \\
1456 & 1487
\end{array}
$$

Wife's share of home production$$
0.6490 \quad 0.4266
$$

$(0.2291)$

(0.1831) 
Table 2: Means and Standard Deviations of Independent Variables Used in Time Use Models

\begin{tabular}{|c|c|c|c|c|}
\hline & $\begin{array}{l}\text { mothers } \\
\text { weekday }\end{array}$ & weekend & $\begin{array}{l}\text { fathers } \\
\text { weekday }\end{array}$ & weekend \\
\hline Age & $\begin{array}{r}35.9252 \\
(7.0251)\end{array}$ & $\begin{array}{r}35.4282 \\
(6.8020)\end{array}$ & $\begin{array}{l}37.9553 \\
(7.3272)\end{array}$ & $\begin{array}{l}37.5047 \\
(7.3554)\end{array}$ \\
\hline Nonwhite & $\begin{array}{r}0.1055 \\
(0.3074)\end{array}$ & $\begin{array}{r}0.1005 \\
(0.3007)\end{array}$ & $\begin{array}{r}0.1262 \\
(0.3322)\end{array}$ & $\begin{array}{r}0.1257 \\
(0.3316)\end{array}$ \\
\hline Hispanic & $\begin{array}{r}0.1503 \\
(0.3575)\end{array}$ & $\begin{array}{r}0.1776 \\
(0.3823)\end{array}$ & $\begin{array}{r}0.1548 \\
(0.3619)\end{array}$ & $\begin{array}{r}0.1602 \\
(0.3669)\end{array}$ \\
\hline Urban residence & $\begin{array}{r}0.6827 \\
(0.4656)\end{array}$ & $\begin{array}{r}0.6764 \\
(0.4680)\end{array}$ & $\begin{array}{r}0.6860 \\
(0.4643)\end{array}$ & $\begin{array}{r}0.6775 \\
(0.4676)\end{array}$ \\
\hline Southern residence & $\begin{array}{r}0.3106 \\
(0.4629)\end{array}$ & $\begin{array}{r}0.3254 \\
(0.4686)\end{array}$ & $\begin{array}{r}0.3023 \\
(0.4594)\end{array}$ & $\begin{array}{r}0.3172 \\
(0.4655)\end{array}$ \\
\hline Num kids 0 to 2 years old & $\begin{array}{r}0.3935 \\
(0.5800)\end{array}$ & $\begin{array}{r}0.4049 \\
(0.5835)\end{array}$ & $\begin{array}{r}0.4043 \\
(0.5724)\end{array}$ & $\begin{array}{r}0.4269 \\
(0.5972)\end{array}$ \\
\hline Num kids 3 to 5 years old & $\begin{array}{r}0.4222 \\
(0.5914)\end{array}$ & $\begin{array}{r}0.4187 \\
(0.5711)\end{array}$ & $\begin{array}{r}0.4409 \\
(0.5874)\end{array}$ & $\begin{array}{r}0.4056 \\
(0.5690)\end{array}$ \\
\hline Num kids 6 to 9 years old & $\begin{array}{r}0.5344 \\
(0.6614)\end{array}$ & $\begin{array}{r}0.5646 \\
(0.6854)\end{array}$ & $\begin{array}{r}0.5532 \\
(0.6719)\end{array}$ & $\begin{array}{r}0.5592 \\
(0.6838)\end{array}$ \\
\hline Num kids 10 to 12 years old & $\begin{array}{r}0.4248 \\
(0.5792)\end{array}$ & $\begin{array}{r}0.3935 \\
(0.5732)\end{array}$ & $\begin{array}{r}0.3830 \\
(0.5697)\end{array}$ & $\begin{array}{r}0.3989 \\
(0.5829)\end{array}$ \\
\hline Num kids 13 to 15 years old & $\begin{array}{r}0.2452 \\
(0.5099)\end{array}$ & $\begin{array}{r}0.2542 \\
(0.5343)\end{array}$ & $\begin{array}{r}0.2539 \\
(0.5311)\end{array}$ & $\begin{array}{r}0.2626 \\
(0.5455)\end{array}$ \\
\hline Presence of other adult & $\begin{array}{r}0.0902 \\
(0.2865)\end{array}$ & $\begin{array}{r}0.0837 \\
(0.2771)\end{array}$ & $\begin{array}{r}0.0902 \\
(0.2866)\end{array}$ & $\begin{array}{r}0.0924 \\
(0.2897)\end{array}$ \\
\hline Summer time diary & $\begin{array}{r}0.2599 \\
(0.4387)\end{array}$ & $\begin{array}{r}0.2446 \\
(0.4300)\end{array}$ & $\begin{array}{r}0.2458 \\
(0.4307)\end{array}$ & $\begin{array}{r}0.2400 \\
(0.4272)\end{array}$ \\
\hline Own predicted ln wage & $\begin{array}{r}2.4172 \\
(0.4144)\end{array}$ & $\begin{array}{r}2.3686 \\
(0.4326)\end{array}$ & $\begin{array}{r}2.9574 \\
(0.3251)\end{array}$ & $\begin{array}{r}2.9367 \\
(0.3322)\end{array}$ \\
\hline $\begin{array}{l}\text { Woman's predicted wage/ } \\
\text { man's predicted wage }\end{array}$ & $\begin{array}{r}0.6125 \\
(0.1765)\end{array}$ & $\begin{array}{r}0.6121 \\
(0.1759)\end{array}$ & $\begin{array}{r}0.8536 \\
(0.2653)\end{array}$ & $\begin{array}{r}0.8593 \\
(0.2810)\end{array}$ \\
\hline $\begin{array}{l}\text { Predicted price of child care } \\
\text { for children } 0 \text { to } 5\end{array}$ & $\begin{array}{r}3.3661 \\
(2.9442)\end{array}$ & $\begin{array}{r}3.3897 \\
(2.9416)\end{array}$ & $\begin{array}{r}2.8826 \\
(2.4539)\end{array}$ & $\begin{array}{r}2.8083 \\
(2.3941)\end{array}$ \\
\hline $\begin{array}{l}\text { Predicted price of child care } \\
\text { for children } 6 \text { to } 12\end{array}$ & $\begin{array}{r}2.0103 \\
(1.9329)\end{array}$ & $\begin{array}{r}1.9322 \\
(1.9367)\end{array}$ & $\begin{array}{r}2.4890 \\
(2.3286)\end{array}$ & $\begin{array}{r}2.4062 \\
(2.2625)\end{array}$ \\
\hline 2003 ATUS & $\begin{array}{r}0.5945 \\
(0.4911)\end{array}$ & $\begin{array}{r}0.6148 \\
(0.4868)\end{array}$ & $\begin{array}{r}0.5818 \\
(0.4934)\end{array}$ & $\begin{array}{r}0.5944 \\
(0.4912)\end{array}$ \\
\hline $\begin{array}{l}\text { Man's usual weekly work } \\
\text { hours }\end{array}$ & $\begin{array}{l}44.8599 \\
(1.9449)\end{array}$ & $\begin{array}{r}44.5853 \\
(1.9714)\end{array}$ & $\begin{array}{r}46.9509 \\
(2.3355)\end{array}$ & $\begin{array}{r}46.9343 \\
(2.3592)\end{array}$ \\
\hline $\begin{array}{l}\text { Woman's usual weekly work } \\
\text { hours }\end{array}$ & $\begin{array}{r}17.3376 \\
(10.4447)\end{array}$ & $\begin{array}{r}16.6839 \\
(10.6886)\end{array}$ & $\begin{array}{r}14.0841 \\
(9.5898)\end{array}$ & $\begin{array}{r}13.9360 \\
(9.7676)\end{array}$ \\
\hline Sample Size & 1497 & 1672 & 1363 & 1504 \\
\hline
\end{tabular}


Table 3a: Marginal Effects of Husband's Variables on Mother's Minutes of Time Use

\begin{tabular}{|c|c|c|c|c|c|c|}
\hline & & Weekdays & & & Weekends & \\
\hline & $\begin{array}{l}\text { lnWmother/ } \\
\text { lnWhusband }\end{array}$ & $\begin{array}{l}\text { Husband's } \\
\text { usual } \\
\text { weekly } \\
\text { work } \\
\text { hours } \\
\end{array}$ & $\begin{array}{l}\text { Husband's } \\
\text { minutes of } \\
\text { time in } \\
\text { same } \\
\text { activity }\end{array}$ & $\begin{array}{l}\text { lnWmother/ } \\
\text { lnWhusband }\end{array}$ & $\begin{array}{l}\text { Husband's } \\
\text { usual } \\
\text { weekly } \\
\text { work hours }\end{array}$ & $\begin{array}{l}\text { Husband's } \\
\text { minutes of } \\
\text { time in } \\
\text { same } \\
\text { activity }\end{array}$ \\
\hline \multicolumn{7}{|l|}{ Leisure } \\
\hline Actual & 73.3382 & $19.0292 * * *$ & --- & $115.2770 *$ & $14.8427 *$ & --- \\
\hline Matched & 8.3154 & 0.0000 & 0.0161 & -28.4753 & -1.8641 & 0.0174 \\
\hline Instrumented & $-85.9693 *$ & -1.2593 & $0.7814 * * *$ & 30.9367 & -0.7123 & $-0.3122 * * *$ \\
\hline \multicolumn{7}{|l|}{ Child Care } \\
\hline Actual & -15.1736 & 2.2829 & --- & -81.4993 & -2.7324 & --- \\
\hline Matched & 13.7155 & 1.5921 & -0.0578 & -7.6955 & 1.3873 & -0.0033 \\
\hline Instrumented & 10.5149 & $4.9432 * *$ & $-0.4891 *$ & -50.8255 & 0.5725 & -0.1403 \\
\hline \multicolumn{7}{|l|}{$\begin{array}{l}\text { Home } \\
\text { Production }\end{array}$} \\
\hline Actual & -19.8694 & -2.7878 & --- & -33.0988 & -2.8159 & --- \\
\hline Matched & -27.0657 & $-4.0200 *$ & 0.0418 & -3.3375 & -0.8517 & 0.0399 \\
\hline Instrumented & -29.0256 & -2.5150 & -0.2300 & -78.4803 & -0.9108 & $0.5538 * *$ \\
\hline
\end{tabular}


Table 3b: Marginal Effects of Wife's Variables on Father's Minutes of Time Use

\begin{tabular}{|c|c|c|c|c|c|c|}
\hline & & Weekdays & & & Weekends & \\
\hline & lnWwife/lnWfather & $\begin{array}{l}\text { Wife’s } \\
\text { usual } \\
\text { weekly } \\
\text { work } \\
\text { hours } \\
\end{array}$ & $\begin{array}{l}\text { Wife's } \\
\text { minutes of } \\
\text { time in } \\
\text { same } \\
\text { activity }\end{array}$ & lnWwife/lnWfather & $\begin{array}{l}\text { Wife’s } \\
\text { usual } \\
\text { weekly } \\
\text { work hours }\end{array}$ & $\begin{array}{l}\text { Wife's } \\
\text { minutes of } \\
\text { time in } \\
\text { same } \\
\text { activity }\end{array}$ \\
\hline Matched & 26.5567 & 0.7563 & 0.0149 & 11.9325 & $1.0182 *$ & -0.0360 \\
\hline Instrumented & -30.5823 & 0.5360 & $0.8622 * * *$ & -56.4549 & 1.9895 & 0.1562 \\
\hline \multicolumn{7}{|l|}{ Child Care } \\
\hline Actual & $49.4829 * * *$ & $2.4002 * * *$ & $\begin{array}{l}-- \\
\end{array}$ & $-69.6416 * *$ & $4.4403 * * *$ & --- \\
\hline Actual & 4.3763 & 0.6868 & --- & 37.2647 & -1.3514 & --- \\
\hline Matched & -6.2372 & 0.3407 & 0.0194 & & 0.9760 & 0.0511 \\
\hline Instrumented & 37.3835 & -0.7228 & -0.2621 & 82.3359 & -1.4296 & 0.0449 \\
\hline
\end{tabular}

* significant at the $10 \%$ level $* *$ significant at the $5 \%$ level $* * *$ significant at the $1 \%$ level

Full results in Tables 4, 5 and 6 
Table 4a: Marginal Effects in Minutes in Activity, Using Actual Spouse Variables, Weekday

\begin{tabular}{|c|c|c|c|c|c|c|}
\hline & \multicolumn{3}{|c|}{ Mothers } & \multicolumn{3}{|c|}{ Fathers } \\
\hline & Leisure & $C C$ & $h p$ & Leisure & Cc & $h p$ \\
\hline \multicolumn{7}{|l|}{ Spouses Economic Variables } \\
\hline \multicolumn{7}{|l|}{ Relative Predicted ln wages } \\
\hline Female lnwage/ male lnwage & 73.3382 & -15.1736 & -19.8694 & -0.6529 & $49.4829 * * *$ & 4.3763 \\
\hline $\begin{array}{l}\text { Spouse's predicted usual } \\
\text { weekly work hours }\end{array}$ & $19.0292 * * *$ & 2.2829 & -2.7878 & -1.3998 & $2.4002 * * *$ & 0.6868 \\
\hline \multicolumn{7}{|l|}{ Own Economic Variables } \\
\hline Own predicted ln wage & $-76.7107 * *$ & $68.3405 * *$ & 2.9529 & -118.9682 & $145.0934 * * *$ & -75.8514 \\
\hline Pcc 0 to 5 year olds & $-10.7834 * * *$ & $5.5202 *$ & 1.0743 & -13.9643 & 14.1553 & -8.5381 \\
\hline Pcc 6 to 12 year olds & -4.4902 & -3.3283 & -34.5672 & -6.8266 & 7.4944 & -9.1288 \\
\hline $\begin{array}{l}\text { Own predicted usual weekly } \\
\text { work hours }\end{array}$ & $-1.8912 * *$ & $-2.0421 * * *$ & $-3.6921 * * *$ & 17.3267 & -18.8703 & 21.3819 \\
\hline \multicolumn{7}{|l|}{ Demographic Variables } \\
\hline Age & -0.6120 & 0.0618 & $2.2067 * *$ & 1.3529 & -1.9688 & 3.4924 * \\
\hline Nonwhite & $31.2534 * *$ & -9.2898 & $-31.1076 *$ & 52.1956 & $-56.5284 *$ & 32.6222 \\
\hline Hispanic & $-23.7229 *$ & -4.4507 & 10.6778 & 10.3435 & -35.3591 & 48.3244 \\
\hline Urban & -6.8068 & 12.1122 & -0.8171 & 40.1372 & -41.3502 & 30.7034 \\
\hline South & $-28.0897 * *$ & 8.1305 & 3.0302 & -43.0230 & $57.5767 *$ & -57.0181 \\
\hline Num kids 0 to 2 & $-28.8883 * *$ & $79.4972 * * *$ & 5.4108 & -29.5007 & $48.5018 * * *$ & 12.3652 \\
\hline Num kids 3 to 5 & 2.0518 & $25.0583 * * *$ & -4.2146 & 2.0949 & $22.3425 *$ & 18.8027 \\
\hline Num kids 6 to 9 & -5.2615 & $20.6198 * * *$ & 12.6495 & -15.5337 & $26.4564 * *$ & -6.4052 \\
\hline Num kids 10 to 12 & $-28.5628 * * *$ & $18.9085 * *$ & $31.9357 * * *$ & -28.1537 & 18.9893 & -14.0418 \\
\hline Num kids 13 to 17 & -13.2400 & -4.2582 & 18.3065 & -28.0402 & 28.1031 & -32.4127 \\
\hline Other adult present & 12.0659 & -22.3453 & 9.3038 & -8.1220 & 12.1142 & 1.9262 \\
\hline \multicolumn{7}{|l|}{ Timing Variables } \\
\hline Summer & 8.6277 & $-32.3516 * * *$ & $29.3263 * * *$ & 39.7180 & $-45.6985 * *$ & 28.1764 \\
\hline Atus2003 & 3.3990 & -1.1688 & -1.2164 & -33.7560 & 20.1360 & -5.4781 \\
\hline Constant & -305.5206 & -143.8507 & 300.4843 & -146.4750 & 388.6350 & -827.7084 \\
\hline
\end{tabular}

* significant at the $10 \%$ level ** significant at the $5 \%$ level ***significant at the $1 \%$ level 
Table 4b: Marginal Effects in Minutes in Activity, Using Actual Spouse Variables, Weekend

\begin{tabular}{|c|c|c|c|c|c|c|}
\hline & Leisure & $c C$ & $h p$ & Leisure & $c C$ & $h p$ \\
\hline \multicolumn{7}{|l|}{ Spouses Economic Variables } \\
\hline \multicolumn{7}{|l|}{ Relative Predicted ln wages } \\
\hline Female lnwage/ male lnwage & $115.2770 *$ & -81.4993 & -33.0988 & -26.5430 & $-69.6416 * *$ & 37.2647 \\
\hline $\begin{array}{l}\text { Spouse's predicted usual } \\
\text { weekly work hours }\end{array}$ & $14.8427 *$ & -2.7324 & -2.8159 & 2.3040 & $4.4403 * * *$ & -1.3514 \\
\hline \multicolumn{7}{|l|}{ Own Economic Variables } \\
\hline Own predicted ln wage & -65.4006 & $98.7052 * * *$ & 1.3164 & 10.2265 & $164.50156 * *$ & 107.1633 \\
\hline Pcc 0 to 5 year olds & -2.7240 & 5.2116 & -0.4010 & -0.0488 & $25.04756 *$ & 6.0425 \\
\hline Pcc 6 to 12 year olds & 0.9014 & $-7.6505 *$ & 5.2638 & 9.8882 & 2.1568 & 3.5740 \\
\hline $\begin{array}{l}\text { Own predicted usual weekly } \\
\text { work hours }\end{array}$ & 0.1393 & -0.2156 & -1.2931 & 4.0073 & -24.7722 & -11.2903 \\
\hline \multicolumn{7}{|l|}{ Demographic Variables } \\
\hline Age & -1.2218 & $1.8373 * *$ & $1.9644 * *$ & -1.8816 & -0.8297 & -0.4189 \\
\hline Nonwhite & 20.6647 & 5.0426 & -8.6667 & 25.5440 & $-72.8264 *$ & -71.1356 \\
\hline Hispanic & -11.1388 & -2.1777 & -4.6349 & 17.1091 & -37.9646 & -40.6006 \\
\hline Urban & 8.3001 & 2.5154 & -1.4949 & -8.9499 & -4.5025 & -19.5035 \\
\hline South & -0.5908 & 10.5905 & -3.4797 & -24.1518 & 62.2368 & 26.0780 \\
\hline Num kids 0 to 2 & $-33.6017 * *$ & $95.1852 * * *$ & -13.3932 & 20.9944 & $115.0304 * * *$ & -29.4767 \\
\hline Num kids 3 to 5 & -15.4788 & $27.1192 * * *$ & -5.2572 & -6.2641 & 37.3382 ** & -17.3652 \\
\hline Num kids 6 to 9 & -6.1988 & $21.8199 * * *$ & -3.1939 & -3.9817 & $67.6162 * * *$ & 0.0288 \\
\hline Num kids 10 to 12 & -16.3778 & -12.3862 & 10.5176 & 21.2145 & 29.3602 & -4.4650 \\
\hline Num kids 13 to 17 & -8.0388 & -10.1015 & 7.6434 & 31.3690 & 33.4400 & 13.2115 \\
\hline Other adult present & -3.8570 & -10.1435 & -23.5470 & 3.9476 & -26.6489 & 13.2428 \\
\hline \multicolumn{7}{|l|}{ Timing Variables } \\
\hline Summer & 8.4118 & $-17.8950 *$ & 3.3980 & 29.1909 & -35.4851 & -22.1070 \\
\hline Atus2003 & 10.6567 & -4.5592 & -0.0401 & 13.2518 & 21.6022 & 3.5923 \\
\hline Constant & -105.9475 & -92.6379 & 357.8701 & 259.0279 & 522.9548 & 416.7580 \\
\hline
\end{tabular}

* significant at the $10 \%$ level $* *$ significant at the $5 \%$ level $* * *$ significant at the $1 \%$ level 
Table 5a: Marginal Effects of Time in Minutes, Using Instrumented Spouse Variables, Weekdays

\begin{tabular}{|c|c|c|c|c|c|c|}
\hline & \multicolumn{3}{|c|}{ Mothers } & \multicolumn{3}{|c|}{ Fathers } \\
\hline & leisure & cc & $h p$ & leisure & cc & $h p$ \\
\hline \multicolumn{7}{|c|}{ Spouse’s Economic Variables } \\
\hline \multicolumn{7}{|l|}{ Relative Predicted ln wages } \\
\hline Female lnwage/ male lnwage & $-85.9693 *$ & 10.5149 & -29.0256 & -30.5823 & $71.1662 *$ & 37.3835 \\
\hline $\begin{array}{l}\text { Spouse's predicted usual } \\
\text { weekly work hours }\end{array}$ & -1.2593 & $4.9432 * *$ & -2.5150 & 0.5360 & 1.4929 & -0.7228 \\
\hline $\begin{array}{l}\text { Spouses predicted minutes in } \\
\text { activity }\end{array}$ & $0.7814 * * *$ & $-0.4891 *$ & -0.2300 & $0.8622 * * *$ & -0.0421 & -0.2621 \\
\hline \multicolumn{7}{|l|}{ Own Economic Variables } \\
\hline Own predicted ln wage & 27.6416 & 50.9352 & -13.8288 & -70.4133 & $113.9044 * * *$ & 46.0977 \\
\hline Pcc 0 to 5 year olds & -2.3892 & $7.2747 * * *$ & 4.9936 & -0.6405 & 1.9632 & 0.3108 \\
\hline Pcc 6 to 12 year olds & 3.1752 & -1.1309 & -0.9940 & 0.8316 & -0.8069 & -4.5135 \\
\hline $\begin{array}{l}\text { Own predicted usual weekly } \\
\text { work hours }\end{array}$ & -1.2164 & -1.6736 & $-2.6889 *$ & 0.1722 & -2.3434 & -2.8112 \\
\hline \multicolumn{7}{|l|}{ Demographic Variables } \\
\hline Age & -0.8998 & 1.6195 & $2.9477 * *$ & 1.6651 & -1.1347 & 0.8482 \\
\hline Nonwhite & -10.1545 & 3.6589 & $-34.9439 *$ & 16.4906 & -24.9204 & -18.1159 \\
\hline Hispanic & $-26.7492 *$ & -17.3545 & -5.5597 & 0.9759 & 13.1468 & -1.7564 \\
\hline Urban & -0.2233 & 16.3480 & 1.3985 & 4.1163 & -5.0268 & -11.2519 \\
\hline South & -2.6031 & 7.2273 & 0.8974 & -9.8697 & 12.2919 & -10.4876 \\
\hline Num kids 0 to 2 & -13.5642 & $108.6678 * * *$ & 5.5004 & 15.8510 & $46.4835 *$ & -10.3829 \\
\hline Num kids 3 to 5 & 10.4468 & $38.8889 *$ & -9.2575 & 12.1236 & $34.6457 * *$ & 1.9955 \\
\hline Num kids 6 to 9 & -0.9849 & $23.5623 *$ & 12.9517 & 1.4368 & $18.3575 * *$ & -2.7794 \\
\hline Num kids 10 to 12 & $-17.3274 *$ & 8.0584 & $27.9919 * * *$ & -4.6748 & 4.5527 & 5.0414 \\
\hline Num kids 13 to 17 & -3.3033 & $-18.1571 * *$ & $21.1642 *$ & 7.5081 & 0.3820 & 1.5784 \\
\hline Other adult present & -4.0280 & $-32.5124 * *$ & $26.6944 *$ & 6.5199 & 13.0521 & 8.9287 \\
\hline \multicolumn{7}{|l|}{ Timing Variables } \\
\hline Summer & 10.5959 & $-43.9727 * * *$ & $18.5748 *$ & 1.5028 & $-23.7601 * *$ & 4.1806 \\
\hline Atus2003 & 3.4761 & 3.2019 & -13.5130 & $-20.5162 *$ & -3.6240 & 12.3586 \\
\hline Constant & 156.7857 & $-292.0418 * * *$ & $288.8952 * * *$ & 171.4406 & $-273.8063 * * *$ & 69.4108 \\
\hline
\end{tabular}

* significant at the $10 \%$ level ** significant at the $5 \%$ level ***significant at the $1 \%$ level 
Table 5b: Marginal Effect of Time in Minutes, Using Instrumented Spouse Variables, Weekends

\begin{tabular}{|c|c|c|c|c|c|c|}
\hline & \multicolumn{3}{|c|}{ Mothers } & \multicolumn{3}{|c|}{ Fathers } \\
\hline & Leisure & $c c$ & $h p$ & leisure & $c c$ & $h p$ \\
\hline \multicolumn{7}{|c|}{ Spouse's Economic Variables } \\
\hline \multicolumn{7}{|l|}{ Relative Predicted ln wages } \\
\hline Female lnwage/ male lnwage & 30.9367 & -50.8255 & -78.4803 & -56.4549 & 59.7032 & 82.3359 \\
\hline $\begin{array}{l}\text { Spouse's predicted usual } \\
\text { weekly work hours }\end{array}$ & -0.7123 & 0.5725 & -0.9108 & 1.9895 & -0.5603 & -1.4296 \\
\hline $\begin{array}{l}\text { Spouses predicted minutes in } \\
\text { activity }\end{array}$ & $-0.3122 * * *$ & -0.1403 & $0.5538 * *$ & 0.1562 & 0.2439 & 0.0449 \\
\hline \multicolumn{7}{|l|}{ Own Economic Variables } \\
\hline Own predicted ln wage & -23.2853 & $103.9425 * * *$ & -17.3677 & 14.8996 & $128.7867 * *$ & 58.1225 \\
\hline Pcc 0 to 5 year olds & 1.8014 & $5.0986 *$ & 0.8352 & -1.5361 & 5.0982 & 2.8162 \\
\hline Pcc 6 to 12 year olds & $7.8460 * *$ & $-7.1478 * *$ & 4.1430 & $12.1424 * * *$ & $-8.7869 * *$ & 0.9936 \\
\hline $\begin{array}{l}\text { Own predicted usual weekly } \\
\text { work hours }\end{array}$ & -1.0713 & 0.5920 & 0.5920 & 2.3559 & -0.3451 & -0.4086 \\
\hline \multicolumn{7}{|l|}{ Demographic Variables } \\
\hline Age & -1.5945 & $2.0243 *$ & 1.4865 & -2.4636 & -0.2007 & 0.7161 \\
\hline Nonwhite & 11.8262 & 13.4524 & -8.2250 & 25.8503 & -21.3740 & $-49.8258 * *$ \\
\hline Hispanic & -29.5053 & -4.4093 & 8.4895 & 6.2517 & -26.4078 & -11.6168 \\
\hline Urban & 14.3425 & -3.6776 & -5.1598 & -22.3427 & 12.4709 & 9.1342 \\
\hline South & 11.0242 & 4.6667 & 2.1242 & -22.4365 & 21.2700 & 0.7821 \\
\hline Num kids 0 to 2 & $-39.3913 *$ & $94.9158 * * *$ & 7.8705 & 15.8428 & 42.7342 & -27.5187 \\
\hline Num kids 3 to 5 & -25.4258 & 23.2431 & 9.1136 & -0.2008 & 12.4633 & -16.3281 \\
\hline Num kids 6 to 9 & -8.6682 & 16.9094 & 8.6698 & -1.9918 & $24.3071 * *$ & -4.2065 \\
\hline Num kids 10 to 12 & -7.5636 & $-18.6506 * *$ & $21.8461 * *$ & $22.3100 *$ & -8.2661 & -9.6996 \\
\hline Num kids 13 to 17 & 6.7174 & -13.6803 & 9.3215 & $29.1685 * *$ & -18.4497 & 2.7952 \\
\hline Other adult present & -25.5761 & -7.0784 & -26.1957 & 2.3387 & -22.2210 & 15.9135 \\
\hline \multicolumn{7}{|l|}{ Timing Variables } \\
\hline Summer & $27.4567 * *$ & $-23.9332 * *$ & 4.8470 & 18.4874 & -0.4122 & -5.9628 \\
\hline Atus2003 & 8.1759 & -3.7742 & -5.7234 & 17.0305 & -6.3939 & -5.2940 \\
\hline Constant & $658.2645 * * *$ & $-250.0723 * *$ & $203.2092 * *$ & 332.4296 * & $-427.8587 * * *$ & -22.8518 \\
\hline
\end{tabular}

* significant at the $10 \%$ level $* *$ significant at the $5 \%$ level $* * *$ significant at the $1 \%$ level 
Table 6a: Marginal Effects in Minutes in Activity, Using Matched Spouse Variables, Weekdays

\begin{tabular}{|c|c|c|c|c|c|c|}
\hline & Leisure & $\begin{array}{l}\text { Mothers } \\
c c\end{array}$ & $h p$ & Leisure & $\begin{array}{l}\text { Fathers } \\
c c\end{array}$ & $h p$ \\
\hline \multicolumn{7}{|c|}{ Spouse's Economic Variables } \\
\hline \multicolumn{7}{|l|}{ Relative Predicted ln wages } \\
\hline Female lnwage/ male lnwage & 8.3154 & 13.7155 & -27.0657 & 26.5567 & $-33.4569 * *$ & -6.2372 \\
\hline $\begin{array}{l}\text { Spouse's predicted usual } \\
\text { weekly work hours }\end{array}$ & 0.0000 & 1.5921 & $-4.0200 *$ & 0.7563 & $0.7084 *$ & 0.3407 \\
\hline $\begin{array}{l}\text { Spouses predicted minutes in } \\
\text { activity }\end{array}$ & 0.0161 & -0.0578 & 0.0418 & 0.0149 & 0.0247 & 0.0194 \\
\hline \multicolumn{7}{|l|}{ Own Economic Variables } \\
\hline Own predicted ln wage & -15.8060 & $59.4560 * * *$ & 3.1741 & -85.7201 & 91.4453 & -88.0439 \\
\hline Pcc 0 to 5 year olds & $-5.6329 *$ & $6.1940 * *$ & 0.5790 & -9.0966 & 7.3100 & -11.1287 \\
\hline Pcc 6 to 12 year olds & 2.7256 & -2.4635 & -4.3852 & -5.1341 & 3.6283 & -10.5549 \\
\hline $\begin{array}{l}\text { Own predicted usual weekly } \\
\text { work hours }\end{array}$ & $-2.3528 * * *$ & $-2.1660 * * *$ & $-3.5814 * * *$ & 10.4773 & -10.0359 & 24.7610 \\
\hline \multicolumn{7}{|l|}{ Demographic Variables } \\
\hline Age & -0.9411 & 0.1345 & $2.3610 * * *$ & 1.1119 & -1.7767 & $3.5479 *$ \\
\hline Nonwhite & 13.2880 & -10.3922 & $-29.1949 *$ & 33.9601 & -31.9008 & 40.0538 \\
\hline Hispanic & $-40.6921 * * *$ & -11.4545 & 12.8929 & -1.2605 & -20.1717 & 52.6053 \\
\hline Urban & 0.0336 & 12.9079 & -2.2379 & 33.6587 & -26.8780 & 35.2084 \\
\hline South & -9.9169 & 8.5967 & -1.3576 & -24.8951 & 25.6940 & $-65.7775 *$ \\
\hline Num kids 0 to 2 & $-33.3472 * * *$ & $78.1121 * * *$ & 6.4611 & -14.5848 & $20.6944 *$ & 4.8691 \\
\hline Num kids 3 to 5 & -3.5888 & $25.1817 * * *$ & -2.6745 & 5.7727 & 12.8858 & 16.6089 \\
\hline Num kids 6 to 9 & -9.3534 & $20.3832 * * *$ & 13.0990 & -3.4614 & 10.4849 & -11.3187 \\
\hline Num kids 10 to 12 & $-16.9870 * *$ & $20.6226 * * *$ & $30.8415 * * *$ & -16.2705 & 2.3360 & -18.5513 \\
\hline Num kids 13 to 17 & -1.0439 & -3.1970 & $16.7444 *$ & -14.6252 & 8.8763 & -39.4471 \\
\hline Other adult present & -5.3066 & $-25.2091 *$ & 10.6273 & -6.1148 & 12.1821 & 1.3326 \\
\hline \multicolumn{7}{|l|}{ Timing Variables } \\
\hline Summer & $22.6268 * *$ & $-29.9209 * * *$ & $26.8759 * * *$ & 29.6140 & $-34.7361 *$ & 31.6670 \\
\hline Atus2003 & -1.3269 & -2.7159 & 0.6397 & -23.5415 & 7.8849 & -9.2515 \\
\hline Constant & $415.4438 * * *$ & -112.3495 & $360.3981 * * *$ & -9.0051 & 272.9577 & -923.6518 \\
\hline
\end{tabular}

$*$ significant at the $10 \%$ level ** significant at the $5 \%$ level $* * *$ significant at the $1 \%$ level 
Table 6b: Marginal Effects in Minutes in Activity, Using Matched Spouse Variables, Weekend

\begin{tabular}{|c|c|c|c|c|c|c|}
\hline & \multicolumn{3}{|c|}{ Mothers } & \multicolumn{3}{|c|}{ Fathers } \\
\hline & Leisure & CC & $h p$ & Leisure & & \\
\hline \multicolumn{7}{|c|}{ Spouse’s Economic Variables } \\
\hline \multicolumn{7}{|l|}{ Relative Predicted ln wages } \\
\hline Female lnwage/ male lnwage & -28.4753 & -7.6955 & -3.3375 & 11.9325 & 13.9767 & \\
\hline $\begin{array}{l}\text { Spouse's predicted usual } \\
\text { weekly work hours }\end{array}$ & -1.8641 & 1.3873 & -0.8517 & $1.0182 *$ & -0.8350 & 0.9760 \\
\hline $\begin{array}{l}\text { Spouses predicted minutes in } \\
\text { activity }\end{array}$ & 0.0174 & -0.0033 & 0.0399 & -0.0360 & -0.0279 & 0.0511 \\
\hline \multicolumn{7}{|l|}{ Own Economic Variables } \\
\hline Own predicted ln wage & 15.3811 & $79.1683 * * *$ & -11.5891 & 2.2322 & $139.1967 *$ & 100.9518 \\
\hline Pcc 0 to 5 year olds & 0.8251 & 3.8844 & -1.3959 & -10.1154 & 4.3176 & 12.7293 \\
\hline Pcc 6 to 12 year olds & $6.4608 *$ & $-8.7651 * * *$ & 4.1472 & 5.5524 & -7.6246 & 6.7557 \\
\hline $\begin{array}{l}\text { Own predicted usual weekly } \\
\text { work hours }\end{array}$ & 0.1383 & -0.7732 & $-1.4130 *$ & 16.3109 & 1.0515 & -19.3224 \\
\hline \multicolumn{7}{|l|}{ Demographic Variables } \\
\hline Age & $-1.6585 *$ & $2.0050 * * *$ & $2.0673 * *$ & -1.3232 & -0.0549 & -0.0070 \\
\hline Nonwhite & 4.0081 & 8.3589 & -5.8801 & 56.2889 & -19.3684 & $-85.8256 * *$ \\
\hline Hispanic & -14.6379 & -8.0491 & -5.5602 & 22.2866 & -18.9808 & -39.0680 \\
\hline Urban & 13.6211 & 2.3041 & -2.3428 & 0.3679 & 14.3841 & -26.4341 \\
\hline South & 15.3474 & 5.2643 & -6.9351 & -45.3737 & 17.3153 & 37.7924 \\
\hline Num kids 0 to 2 & $-34.3155 * *$ & $91.8626 * * *$ & -13.9585 & 4.7598 & $75.8421 * * *$ & -18.9057 \\
\hline Num kids 3 to 5 & -17.1214 & $25.2931 * * *$ & -5.3082 & -6.1744 & $33.2195 *$ & -17.5479 \\
\hline Num kids 6 to 9 & -7.8279 & $19.1847 * * *$ & -3.7352 & $-21.2844 *$ & $33.4516 * * *$ & 9.4848 \\
\hline Num kids 10 to 12 & -7.2257 & $-15.2975 *$ & 8.1608 & 2.8638 & -6.7154 & 5.4588 \\
\hline Num kids 13 to 17 & 1.7364 & -12.6700 & 5.5854 & 6.7223 & -19.8467 & 29.8261 \\
\hline Other adult present & -16.7292 & -10.2545 & -21.0690 & 4.0911 & $-30.9799 *$ & 12.9061 \\
\hline \multicolumn{7}{|l|}{ Timing Variables } \\
\hline Summer & $20.3083 *$ & $-20.2261 * *$ & 1.2612 & 41.1808 & -5.7522 & -33.0948 \\
\hline Atus2003 & 9.6195 & -4.1472 & 0.3789 & 1.3562 & -7.1233 & 12.9285 \\
\hline Constant & $514.4112 * * *$ & $-260.1339 * * *$ & $286.6703 * * *$ & -248.3467 & -484.1253 & 778.4060 \\
\hline
\end{tabular}

$*$ significant at the $10 \%$ level ** significant at the $5 \%$ level ***significant at the $1 \%$ level 
Table 7a: Marginal Effects of Husband's Variables on Mother's Share using Mother's Sample

\begin{tabular}{|l|l|l|l|l|}
\hline & lnWmother/lnWhusband & $\begin{array}{l}\text { Weekdays } \\
\text { Husband's } \\
\text { usual } \\
\text { weekly } \\
\text { work } \\
\text { hours }\end{array}$ & lnWmother/lnWhusband & $\begin{array}{l}\text { Wusband's } \\
\text { usual } \\
\text { weekly } \\
\text { work hours }\end{array}$ \\
\hline Leisure & & & & 0.0000 \\
\hline Matched & -0.0082 & -0.0024 & 0.0353 & 0.0022 \\
\hline Instrumented & $-0.0988^{* *}$ & -0.0012 & 0.0123 & $-0.0238^{* * *}$ \\
\hline Child Care & & & & $-0.0179^{* *}$ \\
\hline Matched & $0.3181^{* * *}$ & $-0.0129 * * *$ & $0.2738 * * *$ & \\
\hline Instrumented & $0.5194^{* * *}$ & -0.0021 & $0.3901 * *$ & -0.0025 \\
\hline $\begin{array}{l}\text { Home } \\
\text { Production }\end{array}$ & & & & -0.0012 \\
\hline Matched & $0.1351^{* * *}$ & -0.0015 & 0.0230 & \\
\hline Instrumented & -0.0019 & -0.0046 & -0.0650 & \\
\hline
\end{tabular}

Table 7b: Marginal Effects of Wife's Variables on Wife's Share of Time Using Father's Sample

\begin{tabular}{|l|l|l|l|l|}
\hline & & Weekdays & & Weekends \\
\hline & lnWwife/lnWfather & $\begin{array}{l}\text { Wife's } \\
\text { usual } \\
\text { weekly } \\
\text { work } \\
\text { hours }\end{array}$ & lnWwife/lnWfather & $\begin{array}{l}\text { Wife's } \\
\text { usual } \\
\text { weekly } \\
\text { work hours }\end{array}$ \\
\hline Leisure & & & & \\
\hline Matched & -0.0236 & $-0.0017^{* * *}$ & $-0.0410^{* *}$ & $-0.0012^{* *}$ \\
\hline Instrumented & 0.0090 & -0.0001 & 0.0450 & -0.0012 \\
\hline Child Care & & & & $-0.0077^{* * *}$ \\
\hline Matched & $0.2997^{* * *}$ & $-0.0110^{* * *}$ & $0.2354 * * *$ & 0.0003 \\
\hline Instrumented & -0.0602 & $-0.0061 * *$ & -0.0114 & \\
\hline $\begin{array}{l}\text { Home } \\
\text { Production }\end{array}$ & & & & $-0.0036^{* * *}$ \\
\hline Matched & 0.0476 & $-0.0029^{* * *}$ & 0.0198 & 0.0009 \\
\hline Instrumented & -0.0561 & -0.0013 & $-0.1233^{*}$ & \\
\hline
\end{tabular}

$*$ significant at the $10 \%$ level ** significant at the $5 \%$ level $* * *$ significant at the $1 \%$ level Full results in Tables 8 and 9 
Table 8a: Wife's Share of Time in Activity, Using Instrumented Spouse Variables, Weekdays

\begin{tabular}{|c|c|c|c|c|c|c|}
\hline & \multicolumn{3}{|c|}{ Mothers } & \multicolumn{3}{|c|}{ Fathers } \\
\hline & leisure & cC & hp & leisure & cC & hp \\
\hline \multicolumn{7}{|c|}{ Spouse's Economic Variables } \\
\hline \multicolumn{7}{|l|}{ Relative Predicted ln wages } \\
\hline Female lnwage/ male lnwage & $-0.0988 * *$ & $0.5194 * * *$ & -0.0019 & 0.0090 & -0.0602 & -0.0561 \\
\hline $\begin{array}{l}\text { Spouse's predicted usual } \\
\text { weekly work hours }\end{array}$ & -0.0012 & -0.0021 & -0.0046 & -0.0001 & $-0.0061 * *$ & -0.0013 \\
\hline \multicolumn{7}{|l|}{ Own Economic Variables } \\
\hline Own predicted ln wage & 0.0369 & $-0.3566 * * *$ & -0.0060 & 0.0708 & $-0.3458 * * *$ & -0.1228 \\
\hline Pcc 0 to 5 year olds & -0.0035 & -0.0090 & $0.0089 *$ & 0.0011 & -0.0048 & 0.0023 \\
\hline Pcc 6 to 12 year olds & 0.0037 & 0.0034 & -0.0006 & 0.0005 & 0.0006 & 0.0089 \\
\hline $\begin{array}{l}\text { Own predicted usual weekly } \\
\text { work hours }\end{array}$ & -0.0010 & -0.0044 & $-0.0061 * * *$ & -0.0016 & $0.0143 * *$ & 0.0070 \\
\hline \multicolumn{7}{|l|}{ Demographic Variables } \\
\hline Age & -0.0006 & $-0.0044 * *$ & $-0.0029 *$ & $-0.0019 *$ & $0.0054 * *$ & 0.0019 \\
\hline Nonwhite & $-0.0249 *$ & 0.0114 & $0.0400 *$ & -0.0227 & $0.0971 * * *$ & 0.0210 \\
\hline Hispanic & -0.0197 & 0.0334 & -0.0295 & -0.0057 & $-0.0717 * *$ & -0.0022 \\
\hline Urban & -0.0062 & -0.0283 & $-0.0431 * *$ & -0.0109 & 0.0072 & 0.0069 \\
\hline South & 0.0011 & $-0.0704 * * *$ & 0.0100 & 0.0136 & $-0.0463 *$ & 0.0049 \\
\hline Num kids 0 to 2 & -0.0037 & $-0.2036 * * *$ & -0.0127 & -0.0065 & -0.0498 & 0.0128 \\
\hline Num kids 3 to 5 & 0.0175 & $-0.1193 * * *$ & -0.0421 & -0.0099 & $-0.0697 *$ & -0.0079 \\
\hline Num kids 6 to 9 & -0.0038 & $-0.1081 * * *$ & 0.0075 & -0.0010 & $-0.0538 * *$ & 0.0095 \\
\hline Num kids 10 to 12 & $-0.0163 *$ & $0.0703 * * *$ & $0.0394 * *$ & 0.0043 & $-0.0362 *$ & 0.0164 \\
\hline Num kids 13 to 17 & -0.0049 & $0.1026 * * *$ & $0.0398 * *$ & -0.0034 & -0.0065 & 0.0072 \\
\hline Other adult present & -0.0107 & $0.1197 * * *$ & -0.0062 & -0.0091 & -0.0392 & -0.0033 \\
\hline \multicolumn{7}{|l|}{ Timing Variables } \\
\hline Summer & 0.0100 & $0.0830 * * *$ & 0.0210 & 0.0032 & 0.0205 & -0.0124 \\
\hline Atus2003 & 0.0028 & -0.0004 & $-0.0278 *$ & $0.0226 * *$ & 0.0254 & -0.0143 \\
\hline Constant & $0.5290 * * *$ & $1.9064 * * *$ & $1.0542 * * *$ & $0.4674 * * *$ & $1.3349 * * *$ & $0.8362 * * *$ \\
\hline
\end{tabular}

* significant at the $10 \%$ level ** significant at the $5 \%$ level ***significant at the $1 \%$ level 
Table 8b: Wife's Share of Time in Activity, Using Instrumented Spouse Variables, Weekends

\begin{tabular}{|c|c|c|c|c|c|c|}
\hline & leisure & $\begin{array}{l}\text { Mothers } \\
\text { cc }\end{array}$ & $h p$ & leisure & $\begin{array}{l}\text { Fathers } \\
\text { cc }\end{array}$ & $p$ \\
\hline Spouse's Economic Variable & & & & & & \\
\hline Relative Predicted ln wages & & & & & & \\
\hline Female lnwage/ male lnwage & 0.0123 & $0.3901 * *$ & -0.0650 & 0.0450 & -0.0114 & $-0.1233 *$ \\
\hline $\begin{array}{l}\text { Spouse's predicted usual } \\
\text { weekly work hours }\end{array}$ & 0.0022 & $-0.0179 * *$ & -0.0012 & -0.0012 & 0.0003 & 0.0009 \\
\hline Own Economic Variables & & & & & & \\
\hline Own predicted ln wage & -0.0361 & -0.1612 & -0.0384 & 0.0281 & $-0.3036 * *$ & -0.1085 \\
\hline Pcc 0 to 5 year olds & 0.0022 & -0.0049 & 0.0017 & 0.0007 & -0.0123 & -0.0056 \\
\hline Pcc 6 to 12 year olds & $0.0062 * *$ & -0.0061 & 0.0050 & $-0.0071 * *$ & $0.0247 * *$ & -0.0039 \\
\hline $\begin{array}{l}\text { Own predicted usual weekly } \\
\text { work hours }\end{array}$ & 0.0015 & $-0.0080 *$ & 0.0008 & $-0.0060 * *$ & 0.0014 & 0.0006 \\
\hline Demographic Variables & & & & & & \\
\hline Age & -0.0001 & $-0.0077 * *$ & 0.0012 & -0.0002 & 0.0026 & 0.0008 \\
\hline Nonwhite & -0.0036 & 0.0193 & 0.0090 & $-0.0292 * *$ & $0.0939 *$ & $0.0459 *$ \\
\hline Hispanic & -0.0005 & $0.0913 * *$ & 0.0091 & -0.0193 & 0.0328 & 0.0072 \\
\hline Urban & $0.0197 * *$ & $-0.0851 * * *$ & -0.0033 & $0.0157 *$ & -0.0234 & -0.0120 \\
\hline South & 0.0128 & $-0.0654 * *$ & -0.0003 & $0.0253 * * *$ & -0.0507 & 0.0024 \\
\hline Num kids 0 to 2 & 0.0056 & $-0.2582 * * *$ & 0.0170 & $-0.0240 *$ & -0.0207 & 0.0281 \\
\hline Num kids 3 to 5 & 0.0031 & $-0.1660 * * *$ & 0.0102 & -0.0039 & 0.0161 & 0.0191 \\
\hline Num kids 6 to 9 & 0.0021 & $-0.1614 * * *$ & 0.0080 & 0.0082 & -0.0473 & 0.0117 \\
\hline Num kids 10 to 12 & -0.0056 & $0.0931 * * *$ & $0.0250 * *$ & -0.0098 & 0.0033 & 0.0181 \\
\hline Num kids 13 to 17 & -0.0053 & $0.1726 * * *$ & 0.0123 & -0.0078 & 0.0456 & 0.0038 \\
\hline Other adult present & $-0.0257 * *$ & $0.1649 * * *$ & -0.0321 & -0.0048 & -0.0153 & -0.0238 \\
\hline Timing Variables & & & & & & \\
\hline Summer & 0.0019 & $0.1702 * * *$ & -0.0075 & 0.0042 & $-0.0971 * * *$ & 0.0080 \\
\hline Atus2003 & $0.0168 * *$ & -0.0310 & -0.0112 & -0.0138 & 0.0048 & 0.0078 \\
\hline Constant & $0.3681 * * *$ & $2.2930 * * *$ & $0.6223 * * *$ & $0.6618 * * *$ & $1.6449 * * *$ & $0.9848 * * *$ \\
\hline
\end{tabular}


Table 9a: Wife's Share of Time in Activity, Matched Spouse Variables, Weekday

\begin{tabular}{|c|c|c|c|c|c|c|}
\hline & \multicolumn{3}{|c|}{ Mothers } & \multicolumn{3}{|c|}{ Fathers } \\
\hline & Leisure & $C C$ & $h p$ & Leisure & $c c$ & $h p$ \\
\hline \multicolumn{7}{|c|}{ Spouse's Economic Variables } \\
\hline \multicolumn{7}{|l|}{ Relative Predicted ln wages } \\
\hline Female lnwage/ male lnwage & -0.0082 & $0.3181 * * *$ & $0.1351 * * *$ & -0.0236 & $0.2997 * * *$ & 0.0476 \\
\hline $\begin{array}{l}\text { Spouse's predicted usual } \\
\text { weekly work hours }\end{array}$ & -0.0024 & $-0.0129 * * *$ & -0.0015 & $-0.0017 * * *$ & $-0.0110 * * *$ & $-0.0029 * * *$ \\
\hline \multicolumn{7}{|l|}{ Own Economic Variables } \\
\hline Own predicted ln wage & $0.0692 * *$ & $0.2148 * * *$ & $-0.1025 *$ & 0.1225 & -0.2582 & 0.0105 \\
\hline Pcc 0 to 5 year olds & -0.0063 & 0.0110 & 0.0004 & 0.0208 & -0.0365 & -0.0012 \\
\hline Pcc 6 to 12 year olds & 0.0045 & 0.0016 & -0.0087 & $0.0140 *$ & -0.0130 & -0.0020 \\
\hline $\begin{array}{l}\text { Own predicted usual weekly } \\
\text { work hours }\end{array}$ & $-0.0057 * * *$ & $-0.0160 * * *$ & $-0.0043 * *$ & -0.0251 & 0.0261 & 0.0064 \\
\hline \multicolumn{7}{|l|}{ Demographic Variables } \\
\hline Age & $-0.0021 *$ & $-0.0088 * * *$ & 0.0022 & -0.0023 & 0.0053 & -0.0011 \\
\hline Nonwhite & 0.0142 & -0.0417 & -0.0132 & -0.0523 & 0.0518 & 0.0449 \\
\hline Hispanic & $-0.0338 *$ & 0.0020 & -0.0329 & -0.0414 & 0.0353 & 0.0189 \\
\hline Urban & $-0.0254 *$ & $-0.0635 *$ & -0.0183 & -0.0619 & 0.0960 & 0.0149 \\
\hline South & 0.0116 & 0.0404 & $-0.0414 *$ & 0.0493 & -0.0402 & 0.0233 \\
\hline Num kids 0 to 2 & $-0.0631 * * *$ & -0.0550 & 0.0161 & 0.0178 & -0.0697 & 0.0149 \\
\hline Num kids 3 to 5 & -0.0139 & $-0.0903 * *$ & -0.0156 & -0.0050 & -0.0766 & -0.0014 \\
\hline Num kids 6 to 9 & $-0.0299 * * *$ & -0.0214 & 0.0114 & 0.0006 & -0.0416 & 0.0216 \\
\hline Num kids 10 to 12 & -0.0126 & 0.0130 & 0.0205 & 0.0238 & -0.0149 & 0.0198 \\
\hline Num kids 13 to 17 & -0.0083 & -0.0140 & 0.0168 & 0.0513 & -0.0728 & -0.0022 \\
\hline Other adult present & -0.0191 & -0.0649 & 0.0397 & 0.0099 & -0.0027 & 0.0020 \\
\hline \multicolumn{7}{|l|}{ Timing Variables } \\
\hline Summer & 0.0115 & $-0.0695 * *$ & 0.0089 & -0.0415 & 0.0693 & -0.0209 \\
\hline Atus2003 & 0.0021 & 0.0351 & 0.0131 & $0.0430 *$ & -0.0352 & -0.0296 \\
\hline Constant & $0.6284 * * *$ & $1.2530 * * *$ & $0.8854 * * *$ & 1.4057 & 0.2609 & 0.4885 \\
\hline
\end{tabular}


Table 9b: Wife's Share of Time in Activity, Matched Spouse Variables, Weekend

\begin{tabular}{|c|c|c|c|c|c|c|}
\hline & \multicolumn{3}{|c|}{ Mothers } & \multicolumn{3}{|c|}{ Fathers } \\
\hline & Leisure & Cc & $h p$ & Leisure & $c C$ & $h p$ \\
\hline \multicolumn{7}{|c|}{ Spouse’s Economic Variables } \\
\hline \multicolumn{7}{|l|}{ Relative Predicted ln wages } \\
\hline Female lnwage/ male lnwage & 0.0353 & $0.2738 * * *$ & 0.0230 & $-0.0410 * *$ & $0.2354 * * *$ & 0.0198 \\
\hline $\begin{array}{l}\text { Spouse's predicted usual } \\
\text { weekly work hours }\end{array}$ & 0.0000 & $-0.0238 * * *$ & -0.0025 & $-0.0012 * *$ & $-0.0077 * * *$ & $-0.0036 * * *$ \\
\hline \multicolumn{7}{|l|}{ Own Economic Variables } \\
\hline Own predicted ln wage & 0.0398 & $0.1890 * *$ & 0.0675 & -0.0321 & -0.3626 & $-0.2755 *$ \\
\hline Pcc 0 to 5 year olds & -0.0041 & 0.0172 & 0.0059 & 0.0020 & -0.0257 & -0.0347 \\
\hline Pcc 6 to 12 year olds & 0.0030 & -0.0237 & 0.0045 & -0.0067 & 0.0115 & -0.0228 \\
\hline $\begin{array}{l}\text { Own predicted usual weekly } \\
\text { work hours }\end{array}$ & $-0.0026 * * *$ & $-0.0104 * * *$ & $-0.0066 * * *$ & -0.0093 & 0.0079 & 0.0517 \\
\hline \multicolumn{7}{|l|}{ Demographic Variables } \\
\hline Age & $-0.0022 * *$ & -0.0009 & 0.0009 & 0.0009 & 0.0048 & 0.0043 \\
\hline Nonwhite & $0.0380 * *$ & 0.0265 & -0.0116 & -0.0200 & 0.1614 & $0.1673 * *$ \\
\hline Hispanic & 0.0119 & -0.0451 & -0.0197 & -0.0240 & 0.0995 & 0.0943 \\
\hline Urban & -0.0023 & 0.0325 & 0.0065 & -0.0010 & -0.0179 & 0.0822 \\
\hline South & 0.0155 & 0.0132 & -0.0223 & 0.0271 & -0.0643 & -0.1178 \\
\hline Num kids 0 to 2 & $-0.0423 * * *$ & 0.0536 & $-0.0734 * * *$ & 0.0043 & $-0.1891 * * *$ & 0.0236 \\
\hline Num kids 3 to 5 & -0.0179 & 0.0230 & $-0.0556 * *$ & 0.0233 & -0.0828 & 0.0429 \\
\hline Num kids 6 to 9 & -0.0095 & 0.0337 & $-0.0302 *$ & $0.0220 * *$ & $-0.1148 * * *$ & -0.0308 \\
\hline Num kids 10 to 12 & -0.0072 & -0.0518 & -0.0096 & -0.0012 & -0.0109 & -0.0458 \\
\hline Num kids 13 to 17 & -0.0091 & -0.0402 & $0.0350 *$ & 0.0052 & 0.0241 & -0.0735 \\
\hline Other adult present & $-0.0300 *$ & -0.0424 & -0.0029 & 0.0121 & 0.0461 & -0.0340 \\
\hline \multicolumn{7}{|l|}{ Timing Variables } \\
\hline Summer & $0.0239 * *$ & -0.0397 & 0.0018 & -0.0168 & -0.0388 & 0.0720 \\
\hline Atus2003 & $0.0229 * *$ & -0.0404 & 0.0294 & 0.0138 & -0.0088 & -0.0201 \\
\hline Constant & $0.5292 * * *$ & $1.2108 * * *$ & $0.7205 * * *$ & 0.9493 & 1.5225 & -1.0105 \\
\hline
\end{tabular}

* significant at the $10 \%$ level ** significant at the $5 \%$ level $* * *$ significant at the $1 \%$ level 